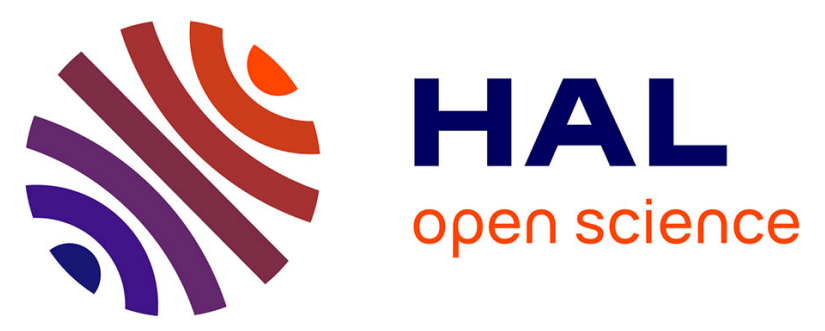

\title{
Wood density proxies of adaptive traits linked with resistance to drought in Douglas fir (Pseudotsuga menziesii (Mirb.) Franco)
}

Manuela Ruiz Diaz Britez, Anne-Sophie Sergent, Alejandro Martinez Meier, Nathalie Bréda, Philippe Rozenberg

\section{To cite this version:}

Manuela Ruiz Diaz Britez, Anne-Sophie Sergent, Alejandro Martinez Meier, Nathalie Bréda, Philippe Rozenberg. Wood density proxies of adaptive traits linked with resistance to drought in Douglas fir (Pseudotsuga menziesii (Mirb.) Franco). Trees - Structure and Function, 2014, 28 (5), pp.1289-1304. 10.1007/s00468-014-1003-4 . hal-01268792

\section{HAL Id: hal-01268792 https://hal.science/hal-01268792}

Submitted on 27 May 2020

HAL is a multi-disciplinary open access archive for the deposit and dissemination of scientific research documents, whether they are published or not. The documents may come from teaching and research institutions in France or abroad, or from public or private research centers.
L'archive ouverte pluridisciplinaire HAL, est destinée au dépôt et à la diffusion de documents scientifiques de niveau recherche, publiés ou non, émanant des établissements d'enseignement et de recherche français ou étrangers, des laboratoires publics ou privés.

$$
\text { Copyright }
$$




\title{
Wood density proxies of adaptive traits linked with resistance to drought in Douglas fir (Pseudotsuga menziesii (Mirb.) Franco)
}

\author{
Manuela Ruiz Diaz Britez • Anne-Sophie Sergent • \\ Alejandro Martinez Meier • Nathalie Bréda • \\ Philippe Rozenberg
}

Received: 17 July 2013/Revised: 25 February 2014/ Accepted: 5 March 2014
C) Springer-Verlag Berlin Heidelberg 2014

\section{Abstract}

Key message Proxies of adaptive traits for resistance to drought were discovered among original annual ring density variables in Douglas fir.

AQ1 Abstract A comparison of dead and surviving Douglas fir trees following the 2003 drought was made to define proxies of adaptive traits for resistance to drought. Increment cores were sampled from trees from three French regions: Centre, Midi-Pyrénées and Burgundy. Original tree-ring variables were calculated, based on a sliding density criterion dividing the microdensity profile into high- and low-density segments. Tree rings were analysed at each site in a number of consecutive annual rings before the 2003 drought event. Comparison between pairs of surviving and dead trees and between pairs of randomly selected trees (whether dead or alive) supports the evidence

Communicated by A. Braeuning.

\section{R. D. Britez}

Parque Tecnológico Misiones, Universidad Nacional de Misiones Félix de Azara 182, Ruta 12 km 7 Miguel Lanus, 3300 Posadas, Misiones, Argentina

M. R. D. Britez · A.-S. Sergent · P. Rozenberg ( $\square)$ INRA Val de Loire, UR0588 Unité d'Amélioration Génétique et Physiologie Forestières, 2163 Avenue de la Pomme de Pin, CS 40001 Ardon, 45075 Orléans Cedex 2, France

e-mail: philippe.rozenberg@orleans.inra.fr

A.-S. Sergent - A. M. Meier

INTA Bariloche, Unidad de Genética Ecológica y Mejoramiento Forestal, CC 277-INTA, 8400 San Carlos de Bariloche,

Río Negro, Argentina

N. Bréda

INRA-UHP UMR 1137 Forest Ecology and Ecophysiology Unit, 54280 Champenoux, France of systematic dissimilarities between surviving and dead trees in a number of original density variables. Correlation analysis between original and conventional ring density variables indicates a weak association. We found that the surviving trees were denser than the dead trees in all three sites, but that the denser part of the ring varied from region to region. We identified several original density variables intended to be used as proxies of adaptive traits in future studies of genetic determinism of Douglas fir resistance to drought.

Keywords Douglas fir · Drought · Mortality · Survival · Adaptation · Adaptive traits - Wood density - Microdensity

\section{Introduction}

The intensity, frequency and duration of drought conditions and heat waves related to climate change are increasing and have already resulted in serious incidences of droughtrelated tree mortality (Adams et al. 2009; Van Mantgem et al. 2009; Allen et al. 2010; Williams et al. 2010; Martinez-Vilalta et al. 2012; Wang et al. 2012; Anderegg et al. 2012, 2013). Climate change projections show that many tree species will be more exposed to potential drought (Hanson and Weltzin 2000; Aber et al. 2001; Jump et al. 2006; Pluess and Weber 2012). Whether forest trees are able to adapt successfully to these increasingly severe and more frequent drought events depend on their ability to evolve. Recent studies tend to demonstrate that there is potential for evolutionary responses to climate change in tree populations (Alberto et al. 2013). The evolutionary mechanism that may enable trees to adapt relies on the magnitude of genetic variation and on the heritability of the adaptive traits involved in resistance to drought. 
Precise estimation of genetic variation and heritability requires measurement of a large number of genotypes and individuals (Cregg 2004; Wortemann et al. 2011). However, the usual methodology applied to drought tolerance studies demands intensive and time-consuming measurements (Cregg 2004; Aranda et al. 2012). Hence, it is necessary to find the putative adaptive traits among more easily measurable drought-resistant traits.

An adaptive trait is related to mating ability, fecundity and/or survivorship, i.e. to fitness (also defined as overall reproductive success). In most studies involving adaptive traits, the relationship with fitness is inferred from the known or supposed involvement of the traits in functional processes. In this article we look for proxies of adaptive traits by calculating their relationship with fitness. Among the fitness components, it is difficult and time consuming to observe mating ability and fecundity in forest trees, while survivorship is much more easily observed. We therefore concentrate on detecting adaptive traits by calculating their relationship with survivorship.

In comparison with other conifer species, Douglas fir is a relatively drought-tolerant species (Eilmann and Rigling 2012). Despite this, some mortality events were observed in Douglas fir stands following the 2003 drought and heat wave in several regions of France. In three regions, Centre, Burgundy and Midi-Pyrénées, (Martinez-Meier et al. 2008a, b); Sergent (2011) and Sergent et al. (2012) have established that such mortality events were induced by soil moisture deficit. In Douglas fir, there is evidence that the xylem structure and some basic wood properties such as density may be directly or indirectly involved in adaptive functional processes and are related to survival. In a previous study of a Douglas fir provenance trial in the Centre region, systematic differences were found between dead trees and surviving neighbours for latewood density traits after the 2003 drought (Martinez-Meier et al. 2008a, b). Sergent (unpublished data) found a relationship between mortality and earlywood density after recurrent drought. Domec and Gartner (2002) suggested that the proportion of earlywood and latewood could be an adaptive trait linked to hydraulic properties in this species. Douglas fir is more drought tolerant when it originates from dry regions (Kavanagh et al. 1999; Pharis and Ferrell 1966). Sergent (2011) found that interior provenances from dry regions had a higher wood density. These results, together with the relationships found between resistance to cavitation (breaking of the water column within the xylem) and wood density in Douglas fir (DallaSalda et al. 2009), show that traits based on wood density components are involved in the response to drought in this species. In this study we selected wood density traits as our candidate proxies of adaptive traits for drought resistance.
Wood density traits used in previous survival studies of Douglas fir were based on ring microdensity profiles. Conventional ring microdensity traits are built from a standard earlywood-latewood boundary criterion established according to Lenz et al. (1976): the density threshold between earlywood and latewood lies exactly at the midpoint between the maximal and the minimal density. This definition of earlywood and latewood is consistent with Mork's index which is based on anatomical differences between these two parts of the ring. The variables based on the earlywood-latewood boundary are called conventional variables hereafter. The definition of an earlywood-latewood boundary is relevant from the wood anatomy perspective, but does not directly hint at any physiological process occurring in the xylem. Thus, the authors wonder whether original ring density variables which are not based on the standard earlywood-latewood boundary would optimize the detection of differential vulnerability to drought-induced mortality in Douglas fir. There are some reports about alternative methods aiming at better utilizing the data contained in ring microdensity profiles (Rozenberg et al. 1999; Koubaa et al. 2005; Ivkovic and Rozenberg 2004; Franceschini et al. 2013). Dalla-Salda et al. (2011) showed that original density traits in Douglas fir which were not based on the earlywood-latewood model were more strongly related to resistance to cavitation than conventional density variables based on the earlywood-latewood model.

The objective of this article is to look for proxies of adaptive traits that should be investigated to evaluate the potential of Douglas fir to evolve and adapt to more frequent and severe drought conditions. In the present study, we decided to investigate the relationship between wood traits and survivorship after drought as a means of defining adaptive traits for drought tolerance. We conducted a new comparison of dead and surviving trees spanning a wide geographical area in France with three experimental sites located in three regions: Centre (CE), Burgundy (BO) and Midi-Pyrénées (MP). We re-analysed the microdensity profiles of the Centre region (Martinez-Meier et al. 2008a, b) and used microdensity profiles collected in Burgundy and Midi-Pyrénées regions (Sergent 2011; Sergent et al. 2012) to extend the study to these two regions. We deepened the tree-ring study and investigated more systematically basic wood properties using a wide-ranging definition of density variables (Rozenberg et al. 1999). We built original annual ring variables according to a sliding density criterion, vertically separating the microdensity profiles into high- and low-density segments. We then tested and compared the potential of these new variables to statistically explain the difference between the surviving and dead trees after drought events. The scope of this article is intentionally limited to the definition and the choice of a 
small set of new wood density traits putatively well suited to the analysis of the genetic determinism of drought resistance.

\section{Materials and methods}

Site description

The sites and years of study were previously described in Martinez-Meier et al. (2008a, b) and Sergent (2011) and Sergent et al. (2012). The most important site characteristics are presented in Table 1. Climatic data were collected from the Météo-France weather station nearest to each site (Martinez-Meier et al. 2008a, b; Sergent et al. 2012).

The Centre region (CE) has, according to Joly et al. (2010), a modified oceanic climate with mild temperature and fairly low precipitation, especially in summer. Burgundy region (BO) has a semi-continental climate, with a higher contrast between summer and winter temperature than the $\mathrm{CE}$ region and higher precipitation. The site of the Midi-Pyrénées region (MP) has a warmer climate than the $\mathrm{CE}$ and $\mathrm{BO}$ region sites, with the greatest contrast between winter and summer temperature. Precipitation is the highest of the three regions, but with a fairly dry summer (Joly et al. 2010).

Douglas fir stands

Three Douglas fir stands were used in this study. In the three experimental trials, mortality was observed and proved to be a consequence of drought events by MartinezMeier et al. (2008a, b) and Sergent (2011) and Sergent et al. (2012).

The first stand is a provenance trial established in 1975 and located in Vitry-aux-Loges, CE region, Forêt d'Orléans, France, with 60 provenances represented in the sample
(Martinez-Meier et al. 2008a, b). Differences due to provenance origin were not considered in this study.

The two other stands are a nine-plot trial from the MidiPyrénées region in the south of France and an 18-plot trial from the Burgundy region in the centre-north-east of France (Sergent 2011; Sergent et al. 2012), respectively. Each plot has at least two dead trees per plot. The selected stands are pure Douglas fir stands with individuals a minimum of 20 years old at the time of sample collection.

Sampling and microdensity profiles

Details of the randomized approach used for sampling the dead and surviving trees are presented in Martinez-Meier et al. (2008a, b). In each trial, several pairs of dead and immediately adjacent surviving trees were selected. In the CE region, 65 pairs were sampled between April and June 2006. In the BO and MP regions, respectively, 45 and 28 pairs were sampled between March and October 2009 (Sergent 2011; Sergent et al. 2012). One radial increment core was extracted at breast height from each tree using a $5.15 \mathrm{~mm}$ AND MATTSON mechanical Pressler borer. In total, 276 increment cores were collected and processed.

The increment cores were analysed using indirect X-ray wood densitometry (Polge 1978). X-ray films were scanned and digital images were processed using the image analysis software Windendro (Guay et al. 1992). The software "Interdat.exe, version 1.1" developed by Dupouey (unpublished) was subsequently used to cross-date the microdensity profiles, to verify and confirm annual ring identification. The software $\mathrm{R}$ was used to control the ring limits and check the quality of the intra-ring density profiles. The cross-dated microdensity profiles were then used and analysed for a number of consecutive years before the 2003 drought, ranging from 1986 to 2002 in CE, and from 1993 to 2002 in MI and BO.

Table 1 Site characterization

\begin{tabular}{|c|c|c|c|c|}
\hline Site & $\begin{array}{l}\text { Mean annual } \\
\text { precipitation }(\mathrm{mm}) \text { for } \\
\text { the period indicated }\end{array}$ & $\begin{array}{l}\text { Annual mean of } \\
\text { minimum } \\
\text { temperature }\left({ }^{\circ} \mathrm{C}\right)\end{array}$ & $\begin{array}{l}\text { Annual mean of } \\
\text { maximum } \\
\text { temperature }\left({ }^{\circ} \mathrm{C}\right)\end{array}$ & Geological background \\
\hline $\begin{array}{l}\text { Centre region }(\mathrm{CE}) \text { Vitry-aux- } \\
\text { Loges, Orléans forest } 47^{\circ} \\
57^{\prime} \mathrm{N}, 2^{\circ} 16^{\prime} \mathrm{E}^{\mathrm{a}}\end{array}$ & $\begin{array}{l}748 \\
1986-2003\end{array}$ & $6^{\circ}$ & $15.9^{\circ}$ & $\begin{array}{l}\text { Mainly sand and clay of geological type } \\
\text { "Sologne" }\end{array}$ \\
\hline $\begin{array}{l}\text { Burgundy region (BO), in NE } \\
\text { of the Massif-Central }^{\text {b }}\end{array}$ & $\begin{array}{l}973 \\
1971-2000\end{array}$ & $-1.5^{\circ} \mathrm{C}$ & $24.6^{\circ}$ & $\begin{array}{l}\text { Plot spreads over a range of bedrock types, } \\
\text { mainly granite, and others such as clay, } \\
\text { basalt and shale }\end{array}$ \\
\hline $\begin{array}{l}\text { Midi-Pyrénées (MP) region, } \\
\text { in SW of France }\end{array}$ & $\begin{array}{l}1,123 \\
1971-2000\end{array}$ & -1.1 & $24.9^{\circ} \mathrm{C}$ & $\begin{array}{l}\text { Plot spreads over a range of bedrock types, } \\
\text { mainly schist and others such as gneiss, } \\
\text { shale and granite }\end{array}$ \\
\hline
\end{tabular}

a From Martinez-Meier et al. (2008a, b)

b From Sergent (2011) 
Definition of the density variables

In the "Introduction" we explained that the annual ring density variables are usually defined according to the position of a boundary between earlywood and latewood which is similar to Mork's definition used in wood anatomy. The annual ring variables based on this earlywoodlatewood model are hereafter referred to as conventional ring variables. In this study we defined a set of unconventional density variables not based on the earlywoodlatewood model. We used an original procedure based on a sliding density criterion (the $d c$ horizontal threshold) defined and used by Rozenberg et al. (1999). The same variables were calculated at two levels: first at the total microdensity profile level and second at the annual ring level. In each case, the microdensity profiles and the annual rings were vertically divided into two parts: high- and lowdensity segments based on the local segment density compared to the $d c$ values (Fig. 1 shows the total microdensity level and Fig. 2 shows the annual ring level). The values of the $d c$ parameter ranged from 0.3 to $0.8 \mathrm{~kg} \mathrm{dm}^{-3}$ with a $0.1 \mathrm{~kg} \mathrm{dm}^{-3}$ increment. For each $d c$ value, the following wood density variables were then calculated: the mean of the high-density segment (the part of the profile which is over the threshold, MHD), the mean of the lowdensity segment (the part of the profile which is under the threshold, MLD), the coefficient of variation of the highdensity segment (CVHD), the coefficient of variation of the low-density segment (CVLD) and the proportion of highdensity segment (the length of the high-density segment divided by the total profile length at the total profile level or by ring width at ring level, PHD). For each variable and each $d c$ value, there is only one value per tree at the total profile level, while there are as many values as there are annual rings in the total profile for the variables calculated at the annual ring level. At the total profile level, an additional variable was calculated: the number of intersections between the microdensity profile and the $d c$ threshold, referred to as the number of crossing points (CP). The total number of original variables calculated is 36 at the profile level and 30 at the annual ring level (i.e. six $d c$ values times the number of original variables, Figs. 1 and 2). All calculations used computer routines written in R language (R Core Team 2013).

\section{Statistical analysis}

To investigate the possible differences between surviving and dead trees for all original variables, we used the following statistical analysis: for each variable, an ad hoc Monte Carlo procedure was applied to construct a reference population of differences between trees of randomly associated pairs, without replacement and without consideration of health status

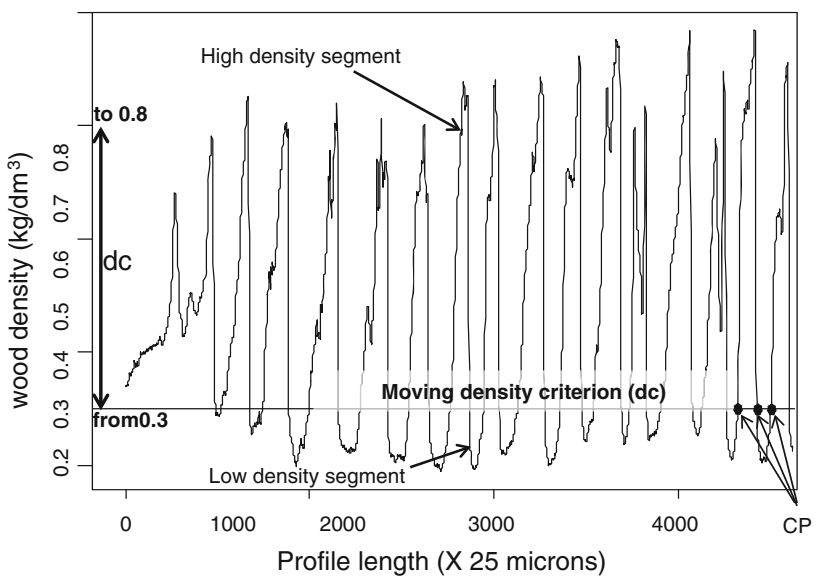

Fig. 1 Applying a sliding density criterion $(d c)$ vertically and dividing the microdensity profile into two density segments: one high density and one low density. Here, the value of $d c$ is $0.3 \mathrm{~kg} \mathrm{dm}^{-3}$. Some crossing points between $d c$ and the microdensity profile are shown $(C P)$

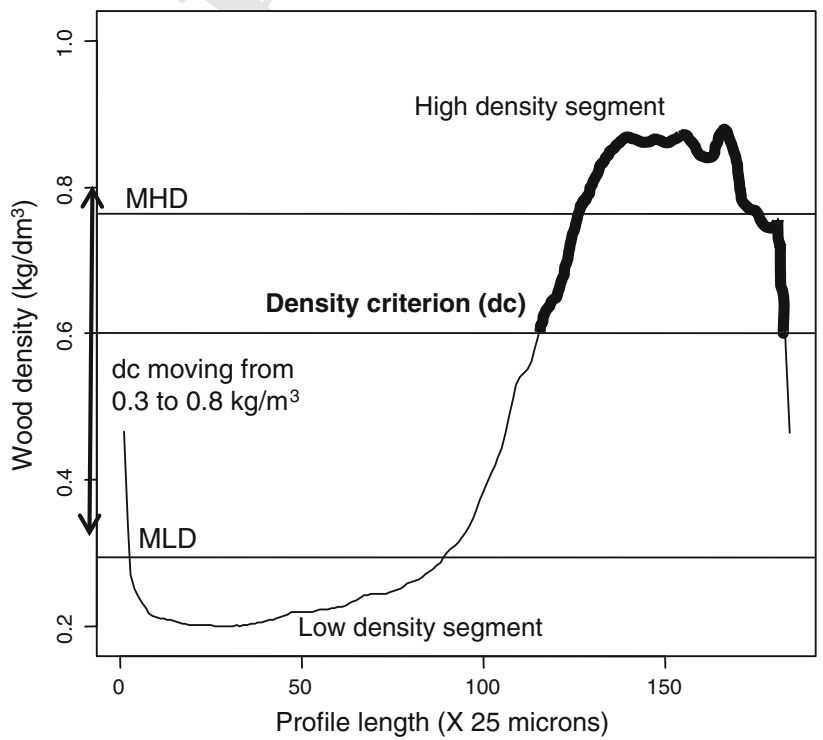

Fig. 2 Applying a sliding density criterion $(d c)$ vertically and dividing the annual ring into two density segments: a high-density segment and a low-density segment. Here the value of $d c$ is $0.6 \mathrm{~kg}$ $\mathrm{dm}^{-3}$. The mean of the high-density segment $(M H D)$ and of the lowdensity segment $(M L D)$ are shown

(Martinez-Meier et al. 2008a, b). By bootstrapping these random differences 10,000 times, the reference population constructed follows a normal distribution with a mean of zero. This reference population was then used for hypothesis testing on observed mean differences between dead and surviving trees. This enabled the optimum value for the moving density criterion $(d c)$ that enhances the discrimination between the surviving and dead trees to be recorded. Randomization was carried out using a Monte Carlo routine written in R language 
Table 2 Absolute value of $\log 10$ of associated probabilities of observed mean differences between surviving and dead trees under $\mathrm{H}_{0}=$ no difference for original variables calculated at the total microdensity profile level

$d \mathrm{c}$ density criterion, $\log 10$ of associated probabilities, $n s$ not significant

$(* * *)$ for $p<0.001,(* *)$ for $p<0.01$ and $(*)$ for $p<0.05$

( $\mathrm{R}$ Core Team 2013). The results are presented as the $\log 10$ of the probabilities associated with the observed differences between the surviving and dead trees. Descriptive statistics summarizing mean, standard deviation, coefficient of variation and box plot analysis were calculated for each variable per site.

To study the relationship between the conventional ring variables and our original ring variables, we performed a Pearson product-moment correlation analysis taking into account a data matrix combining the information on all the individual trees and the annual rings studied from the three sites. The selected conventional variables are ring width (RW), mean ring density (MRD) and other conventional variables chosen among those found to be significantly related to induced cavitation resistance by Dalla-Salda et al. (2011) Thus, we expect them to be involved in survival of drought by trees. The variables are minimum ring density (MID), maximum ring density (MAD), earlywood density (EWD), latewood density (LWD) and earlywood proportion (EWP). A non-conventional variable defined by Dalla-Salda et al. (2011) and strongly related to resistance to cavitation, the mean of the first 100 density values along earlywood (SEQ), was also added.

\section{Results}

We found significant differences between dead and surviving trees for several of our original variables, at least for some values of $d c$ and in some regions (Table 2). The variables for which the differences were most significant varied from region to region.

Table 2 shows the statistics ( $\log 10$ of the probability) of the test used to investigate the differences between surviving and dead trees at the total microdensity profile level in the three regions.

In the $\mathrm{CE}$ region, significant differences between surviving and dead trees were found for all the high-density segment variables. The surviving trees are significantly different from their dead counterparts in MHD (mean of the high-density segment) across all the $d c$ values, PHD (proportion of the high-density segment) for the $d c$ values from 0.5 to $0.8 \mathrm{~kg} \mathrm{dm}^{-3}$ and CVHD (coefficient of variation of the high-density segment) for the $d c$ values of $0.3 \mathrm{~kg} \mathrm{dm}^{-3}$ and between 0.7 and $0.8 \mathrm{~kg} \mathrm{dm}^{-3}$. The surviving trees appear to be significantly different from the dead trees in CP (number of cross points) in the range of the $d c$ values between 0.4 and $0.8 \mathrm{~kg} \mathrm{dm}^{-3}$.

In all cases, the surviving trees have a significantly higher density (higher MHD), a higher number of cross points (CP) and a higher proportion of high-density segments (PHD) than the dead trees (Table 2).

No significant differences were observed for the variables of the low-density segments in this site.

In the MP region, the surviving and dead trees are significantly different for all the variables of both the highand low-density segments, except CVLD. The surviving 
trees are significantly different from their dead counterparts in MHD, MLD (mean of the low-density segment) and PHD in the whole range of the $d c$ values. Highly significant differences are observed for CVHD for the $d c$ values of 0.3 and $0.7 \mathrm{~kg} \mathrm{dm}^{-3}$. For all the variables in this site except CVLD, the surviving trees have higher values than the dead trees (Table 2).

In the BO region, the surviving trees are significantly different from the dead trees in MLD for $d c$ values in the range $0.3-0.5$ and for $d c$ equalling $0.8 \mathrm{~kg} \mathrm{dm}^{-3}$. Significant differences are observed in CP for the $d c$ value $0.5 \mathrm{~kg}$ $\mathrm{dm}^{-3}$ (Table 3 ). The surviving trees have a significantly higher density in the low-density segment (higher MLD) than the dead trees for almost all the $d c$ values and a higher number of cross points (CP) only for $d c$ value $0.5 \mathrm{~kg} \mathrm{dm}^{-3}$ (Table 2). No significant differences were observed in the variables of the high-density segment in this site.

The denser microdensity profiles of the surviving trees of the three regions are illustrated in Fig. 3.

Figure 3 illustrates the main trends of the results in the three regions.

At the annual ring level, the difference between the dead and surviving trees is observed year by year in each annual ring before 2003 (Tables 4, 5 and 6). In the $\mathrm{CE}$ region, the differences between dead and surviving trees began to be significant for the high-density segment variables generally in the 1990 annual ring (Table 4 annex Tables). For MHD the effect was significant across all the $d c$ values, while for PHD it was significant for the $d c$ values between 0.5 and $0.8 \mathrm{~kg} \mathrm{dm}^{-3}$. In subsequent annual rings, the surviving trees appeared to be significantly different from the dead trees from the annual ring 1994 up to the annual ring 2002 for both variables, for a range of $d c$ values and with different levels of significance $(p<0.05$ to $p<0.001)$. The strongest differences were observed immediately before 2003. The range of the $d c$ critical values was located between 0.4 and $0.7 \mathrm{~kg} \mathrm{dm}^{-3}$, for MHD and between 0.5 and $0.8 \mathrm{~kg} \mathrm{dm}^{-3}$ for PHD (Table 4). The surviving and dead trees also appeared to be significantly different for CVHD for several $d c$ values, in particular the annual rings 1994, 1995 and 2002. For MLD, in the low-density segment, some differences were observed for some $d c$ values for a few years (i.e. 1994, 1997 and 2001). No significant differences were observed for CVLD (Table 4).

In the MP region, significant differences between the surviving and dead trees were observed for almost all the annual rings from 1993 to 2002 for MHD and MLD, in both the high- and low-density segments, for several $d c$ values and levels of significance (Table 5). The critical range for MHD was located between 0.4 and $0.6 \mathrm{~kg} \mathrm{dm}^{-3}$ while for MLD it was between 0.3 and $0.5 \mathrm{~kg} \mathrm{dm}^{-3}$. In this site, significant differences between the surviving and dead trees were observed for PHD and CVHD in several annual rings before 2003. The critical range of the $d c$ values was located between 0.7 and $0.8 \mathrm{~kg} \mathrm{dm}^{-3}$ for PHD, while it was between 0.3 and $0.5 \mathrm{~kg} \mathrm{dm}^{-3}$ and from 0.6 to $0.8 \mathrm{~kg} \mathrm{dm}^{-3}$ for CVHD. No significant differences were observed for CVLD.

In the $\mathrm{BO}$ region, the annual rings of the surviving trees appeared to be significantly different from those of the dead trees, from 1996 up to 2001 for MLD, in the lowdensity segment, with different levels of significance (Table 6). The critical $d c$ values were variable and dependent on the year and were distributed between 0.3 and 0.5 or $0.6 \mathrm{~kg} \mathrm{dm}^{-3}$ (Table 4.). For the variables linked to the high-density segment, the surviving trees appeared to be significantly different from the dead trees in few $d c$ values in only one annual ring (1998) for MHD, CVHD and PHD.

In all three regions, for all the variables with significant differences between the surviving and dead trees, the surviving trees had a higher density (higher MHD and MLD), a higher proportion of high-density segment (PHD) and a higher within-segment variation (higher CVHD and CVLD). The denser microdensity profiles of the surviving trees in the three regions are illustrated in Fig. 3.

The results of the correlation study between the original and the conventional variables are presented in Table 7 (Annex Tables). In general, weak or relatively weak values of the correlation coefficient (lower than 0.70) or not significant association was observed between the original and the conventional ring variables. The only exception was a high degree of positive association between LWD and MHD for almost all $d c$ values.

\section{Discussion}

According to our results, the original microdensity variables used in this study reveal systematic differences between surviving and dead trees in Douglas fir. These results support those obtained in the $\mathrm{CE}$ region with the conventional microdensity variables only (Martinez-Meier et al. 2008a, b), increasing the statistical significance of the tests and extending this result to the two new regions BO and MP.

At the total profile level, the only variable which highly discriminates the dead from the surviving trees in all three regions is $\mathrm{CP}$ (Table 3 ). It is the sole trait calculated only at the total profile level. For a given $d c$ value, the higher the $\mathrm{CP}$ value, the higher are the number and height of the density peaks in the profile. The surviving trees have a higher $\mathrm{CP}$ than the dead trees, hence they react more strongly and/or more frequently to environmental variation: in other words, they are more plastic. MLD is the main discriminating trait in the MP and $\mathrm{BO}$ regions, followed by PHD, CVHD and more marginally by MHD. 
Trees Version définitive du manuscrit publié dans / Final version of the manuscript published in :

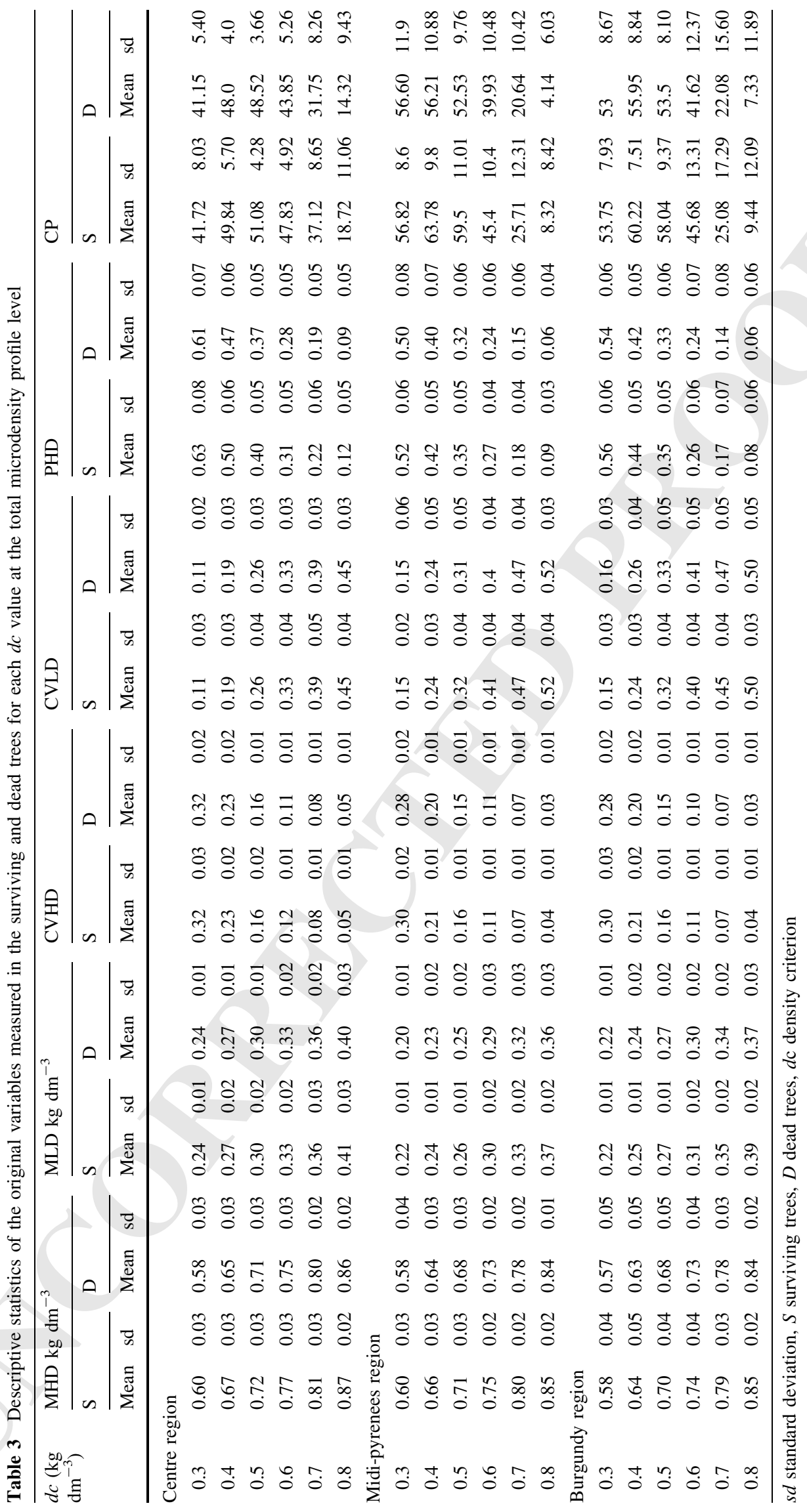


MHD, PHD and CVHD are the most discriminating traits in the CE and MP regions (Table 3). As a consequence, in the $\mathrm{CE}$ and MP regions, the surviving trees have a higher proportion of higher-density wood than the dead trees. In the $\mathrm{MP}$ and $\mathrm{BO}$ regions, the surviving trees have a higher density of low-density segment.

The results obtained at ring level corroborate and specify the trends observed at the total profile level (Tables 4, 5 and 6 in Annex Tables). PHD, MHD, MLD and CVHD are discriminating traits in the three regions, with a variable ranking of their discrimination power between regions. As for the total profile traits, we find that the surviving trees have a higher density, proportion and variation of the high-density segments in many annual rings than the dead trees in the $\mathrm{CE}$ and $\mathrm{MP}$ regions and, to a lesser extent, in the $\mathrm{BO}$ region. In the $\mathrm{BO}$ and MP regions, the surviving trees also have a higher density of low-density segments in many annual rings (Fig. 3).

In our study, there are converging significant results for $\mathrm{CP}$ and CVHD for the $d c$ values between 0.5 and $0.8 \mathrm{~kg}$ $\mathrm{dm}^{-3}$ in the CE region and between 0.7 and $0.8 \mathrm{~kg} \mathrm{dm}^{-3}$ in the MP region. These results indicate that the microdensity profiles of the surviving trees are more heterogeneous than those of the dead trees. We suggest that the surviving trees may react more strongly and/or more frequently to variation in water availability: the surviving trees may be more plastic than the dead trees.

In all cases, the mean density of the surviving trees is higher than that of the dead trees (Fig. 3). However, the denser part of the ring is different from region to region. This may reflect variation among the three regions in terms of the attributes of the drought episodes leading to the observed diebacks. Some results suggest that, depending on the characteristics of a drought, the critical part of the ring may be different: Domec and Gartner (2002) have shown that latewood was more vulnerable to embolism than earlywood in high trunk water potential, but as trunk water potential decreased, the latewood showed very little further embolism. They also suggested that latewood is a water storage organ that can release water at very small water potential differences. Dalla-Salda et al. (2011) found that during the cavitation process, the low water potential controlling early embolism was related to latewood density, while the high water potential controlling late embolism was related to earlywood density. Furthermore, during a spring drought only earlywood is present in the current annual ring, while during a late summer drought both earlywood and latewood exist. This indicates that, according to the residual conductance of the successive sapwood rings, the dynamics, the seasonal progression and the intensity of the drought, earlywood and latewood may play different roles in cavitation resistance.
Selection of adaptive variables

At ring level, we used the number of annual rings with significant differences between surviving and dead trees to select the proxies for adaptive traits for resistance to drought: the most discriminant traits in the largest number of annual rings were assumed to be the best candidates. For most traits the $d c$ value had little effect on the discriminating power: MHD, PHD and CVHD have more or less the same discriminating power for any value of $d c$. Conversely, MLD is always more discriminant when it is calculated for the lowest $d c$ values, i.e. $0.3,0.4$ and $0.5 \mathrm{~kg} \mathrm{dm}^{-3}$. We selected MHD (mean of the high-density segment), PHD (proportion of the high-density segment) and CVHD (coefficient of variation of the high-density segment) calculated at any $d c$ level and MLD calculated at the $d c$ values $0.3,0.4$ and $0.5 \mathrm{~kg} \mathrm{dm}^{-3}$ as the best adaptive traits for resistance to drought. These traits will be used in another study for estimating the genetic determinism of resistance to drought in Douglas fir. If these traits are found to be adequately genetically variable and heritable, then it will be possible to select more droughtresistant trees in breeding populations and in forest stands intended to be naturally regenerated.

Original and conventional variables

Of the three sites, the original variables better explain the difference between the surviving and dead trees than the conventional variables in the CE region (Martinez-Meier et al. 2008a, b). The original variables based on the sliding density criterion have the advantage of providing a relatively finer localization of the wood segment that is critical for survival. The original variables are based on a sliding density criterion separating the total profile or the ring density profile into high- and low-density segments. This definition can be understood as an extension of the earlywood-latewood model. Thus, we expected strong or very strong correlations between several original and conventional variables. However, we found high correlation values only between latewood density and MHD (mean of the high-density segment, Table 7 in Annex Tables). In general, weak or not significant correlation coefficient values indicate that the original variables can be considered a new set of variables with no phenotypic correlation with conventional ring variables.

As expected, the conventional variables have a lower discriminating power than the original variables (results not shown). Only LD (latewood density) has a similar discriminating power to MHD (mean of the high-density segment) for $d c$ values over $0.5 \mathrm{~kg} \mathrm{dm}^{-3}$. This is consistent with the high correlation coefficient found between these two variables.

\section{7}

518

519

520

521

522

523

524

525

526

527

528

529

530

531

532

533

534

535

536

537

538

539

540

541

542

543 
Fig. 3 Average microdensity profiles of the dead (black line) and surviving (red line) trees of the three regions. a the Centre region, b Burgundy region and each region the annual ring density profiles were standardized to the same number of density values (30), then averaged at the level of the dead and surviving trees and put together to reconstruct a total microdensity profile c the Midi-Pyrénées region. In
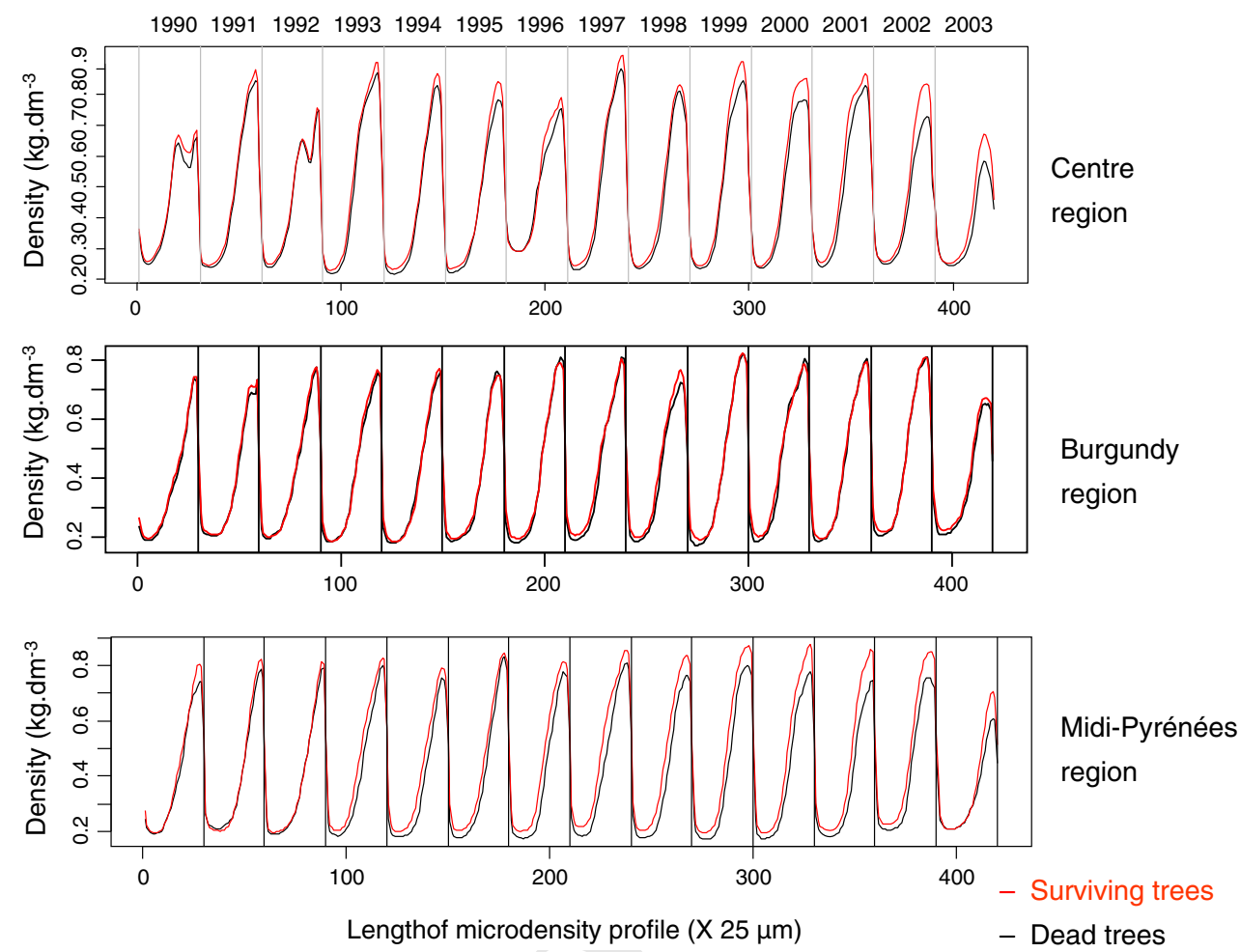

High-density wood, survival and drought

Negative relationships across species between wood density and survival have often been found in tropical forests (Kraft et al. 2010). Martinez-Vilalta (2010) observed the same pattern across temperate and Mediterranean species. Fewer results are available at the intraspecific level: $\mathrm{Ku}-$ kowski et al. (2013) found that mortality rates correlated with wood density in oak and elm. Across or intra-species, the mortality factors are not often clearly identified. When they are, they include mechanical breakdown, attack by pathogens and fungi (Poorter et al. 2010; Larjavaara and Muller-Landau 2010) and, in few cases, drought-induced embolism (Hiromi et al. 2012; Kukowski et al. 2013). This is the case in our study, where Martinez-Meier et al. (2008a, b) and Sergent (2011) and Sergent et al. (2012) demonstrated that the main factor in Douglas fir mortality in all three regions was water deficit.

In Douglas fir, wood density is strongly related to wood anatomy: wood density is mainly related to cell wall thickness and cell diameter (Rathgeber et al. 2006). The wider tracheids associated with low-density wood increase the risk of cavitation, causing water conduction to decline if cells become embolized (air filled) and leading to tree death in extreme cases (Hacke et al. 2001; Hacke and Sperry 2001; Cruiziat et al. 2002; Breda et al. 2006). We therefore conclude that, in Douglas fir, the lower mortality rate of the high-density individuals correlates with an increased resistance to droughtinduced embolism. Such a conclusion is consistent with the negative relationship found in Douglas fir between density and resistance to cavitation (Dalla-Salda et al. 2011). This result may not relate to other species, since in some trees such as Norway spruce (Rosner et al. 2007) and maritime pine et al. (2013) proposed that cavitation resistance was related to tree mortality during extreme drought events. Wortemann et al. (2011) found no variation between populations and concluded that cavitation resistance was probably not an adaptive trait submitted to selection. These results may suggest that in these species, adaptation to drought may depend more on traits such as stomatal closure, leaf abscission and carbon storage rather than on xylem resistance to embolism may not play the same critical role as in Douglas fir.

Directional selection

In their study based on conventional ring data from the Centre region Martinez-Meier et al. (2008) wrote that “(...) some degree of selection against trees with low-density wood may happen after heat wave events like the one in 2003". Our results suggest that directional selection is occurring in the Douglas fir stands of the Centre, Midi-Pyrénées and Burgundy regions following the dieback triggered by the 2003 drought event. This directional selection does not orient Douglas fir to a unique drought-resistant phenotype. The magnitude of the density increase and the part of the ring
588

572

573

574

575

576

577

578

579

580

581

582

583

584

585

586

587

589

590

591

592

593

594

595

596

597

598 (Lamy et al. 2011, 2012) no relationship was found between wood density and resistance to cavitation. In beech, Barigah (Jones 1992; McDowell et al. 2008) and that wood density 
which is modified are different from region to region. In the Centre region the density increase is significant only in the high-density wood (similar to latewood) and reaches $0.015 \mathrm{~kg} \mathrm{dm}^{-3}$ on average. In Burgundy region the density increase is significant only in the low-density wood (similar to earlywood) and reaches $0.008 \mathrm{~kg} \mathrm{dm}^{-3}$. In the Midi-Pyrénées region the density increase is significant in both types of wood and reaches 0.020 and $0.012 \mathrm{~kg} \mathrm{dm}^{-3}$ in the high and low-density wood, respectively (results not shown). Whether these phenotypic changes are functionally significant and whether they will be transferred to the next generations will be the subject of future studies.

\section{Conclusion and perspectives}

According to Domec and Gartner (2002), hydraulic safety is a primary force of natural selection acting on wood structure in Douglas fir. In the present study, we dealt with the problem of defining proxies of wood-based adaptive traits in Douglas fir, specifically traits that maximize the survival of individuals in water-constrained environments. We found that it is possible to define a new set of proxies of adaptive traits with a high discriminating power between surviving and dead individuals. These proxies can be used to estimate the potential of evolutionary adaptation of Douglas fir to drought. The evolutionary mechanism that enables plants to adapt relies on the magnitude of genetic variation and of heritability. Hence, the next step is to precisely estimate the genetic variation and the heritability of the original proxies of adaptive traits based on the density profiles that we discovered in this study.

Acknowledgments We gratefully thank F. Gérémia, Y. Lefèvre, N. Métral, P. Behr, T. Paul and B. Issenut for their technical assistance during field data collection and F. Millier for fieldwork and laboratory measurements. The fieldwork was possible thanks to the help of agents from CRPF in the Midi-Pyrénées and Burgundy. We thank L. Sanchez and S. Marin for discussions during the preliminary steps of the study. We also thank all public and private forest owners for allowing tree coring. The research was funded by the National Research Agency (DRYADE project, ANR-06-VULN-004), the Centre region Research Project Xylome ${ }^{\circ} 200900038263$ and the Regional Council of Burgundy region. A.S. Sergent received a PhD grant from the Regional Council of Centre region, France, M. RuizDiaz received fundings from the Parque Tecnológico Misiones and the Universidad Nacional de Misiones, Argentina.

Conflict of interest The authors declare that they have no conflict of interest.

\section{Annex}

See Annex Tables 4, 5, 6, 7

Table $4 \log 10$ of associated probabilities of observed mean differences between surviving and dead trees under $\mathrm{H}_{0}=$ no difference for original variables calculated at the annual ring level in Centre region

Centre region

\begin{tabular}{llllll}
\hline MHD & & & & & \\
\hline$d c$ & & & & & \\
\hline 0.3 & 0.4 & 0.5 & 0.6 & 0.7 & 0.8 \\
\hline
\end{tabular}

\section{MLD}

$d c$

\begin{tabular}{llllll}
\hline 0.3 & 0.4 & 0.5 & 0.6 & 0.7 & 0.8 \\
\hline
\end{tabular}

Annual ring

\begin{tabular}{|c|c|c|c|c|c|c|c|c|c|c|c|c|}
\hline 1986 & $0.21 \mathrm{~ns}$ & $0.60 \mathrm{~ns}$ & $0.60 \mathrm{~ns}$ & $0.46 \mathrm{~ns}$ & $0.44 \mathrm{~ns}$ & $0.38 \mathrm{~ns}$ & $0.74 \mathrm{~ns}$ & $0.88 \mathrm{~ns}$ & $0.70 \mathrm{~ns}$ & $0.60 \mathrm{~ns}$ & $0.5 \mathrm{~ns}$ & $0.54 \mathrm{~ns}$ \\
\hline 987 & $0.23 \mathrm{~ns}$ & $0.15 \mathrm{~ns}$ & $0.12 \mathrm{~ns}$ & $0.08 \mathrm{~ns}$ & $0.50 \mathrm{~ns}$ & $0.43 \mathrm{~ns}$ & $0.20 \mathrm{~ns}$ & $0.26 \mathrm{~ns}$ & $0.46 \mathrm{~ns}$ & $0.52 \mathrm{~ns}$ & $1.47^{*}$ & $0.65 \mathrm{~ns}$ \\
\hline 988 & $0.30 \mathrm{~ns}$ & $0.34 \mathrm{~ns}$ & $0.30 \mathrm{~ns}$ & $0.25 \mathrm{~ns}$ & $0.32 \mathrm{~ns}$ & $0.18 \mathrm{~ns}$ & $0.40 \mathrm{~ns}$ & $0.56 \mathrm{~ns}$ & $0.56 \mathrm{~ns}$ & $0.54 \mathrm{~ns}$ & $0.52 \mathrm{~ns}$ & $0.55 \mathrm{~ns}$ \\
\hline 989 & $0.37 \mathrm{~ns}$ & $0.46 \mathrm{~ns}$ & $0.62 \mathrm{~ns}$ & $0.73 \mathrm{~ns}$ & $0.52 \mathrm{~ns}$ & $0.44 \mathrm{~ns}$ & $0.1 \mathrm{~ns}$ & $0.33 \mathrm{~ns}$ & $0.43 \mathrm{~ns}$ & $0.36 \mathrm{~ns}$ & $0.09 \mathrm{~ns}$ & $0.07 \mathrm{~ns}$ \\
\hline 990 & $2.17 * *$ & $2.58 * *$ & $2.87 * *$ & $1.90 *$ & $2.66 * *$ & $0.70 \mathrm{~ns}$ & $0.22 \mathrm{~ns}$ & $0.47 \mathrm{~ns}$ & $0.32 \mathrm{~ns}$ & $0.03 \mathrm{~ns}$ & $0.15 \mathrm{~ns}$ & $1.35 *$ \\
\hline 991 & $0.56 \mathrm{~ns}$ & $1.16 \mathrm{~ns}$ & $1.50 *$ & $1.40 *$ & $1.20 \mathrm{~ns}$ & $0.80 \mathrm{~ns}$ & $0.31 \mathrm{~ns}$ & $2 \mathrm{~ns}$ & $0.70 \mathrm{~ns}$ & $0.5 \mathrm{~ns}$ & $0.22 \mathrm{~ns}$ & $0.28 \mathrm{~ns}$ \\
\hline 992 & $0.60 \mathrm{~ns}$ & $0.65 \mathrm{~ns}$ & $0.38 \mathrm{n}$ & $0.42 \mathrm{~ns}$ & $0.82 \mathrm{~ns}$ & $0.83 \mathrm{~ns}$ & $0.19 \mathrm{~ns}$ & $0.34 \mathrm{~ns}$ & $2 \mathrm{~ns}$ & $0.34 \mathrm{~ns}$ & $36 \mathrm{~ns}$ & $44 \mathrm{~ns}$ \\
\hline 993 & $0.57 \mathrm{~ns}$ & $0.73 \mathrm{~ns}$ & $1.00 \mathrm{n}$ & $0.94 \mathrm{~ns}$ & $1.46^{*}$ & $1.53 *$ & $0.65 \mathrm{~ns}$ & $\mathrm{~ns}$ & $0.89 \mathrm{~ns}$ & $0.36 \mathrm{~ns}$ & $0.47 \mathrm{~ns}$ & $0.16 \mathrm{~ns}$ \\
\hline 994 & $0.64 \mathrm{~ns}$ & $0.93 \mathrm{~ns}$ & $1.40 *$ & $2.23 * *$ & $1.70^{*}$ & $1.76^{*}$ & $1.56^{*}$ & $1.46^{*}$ & $1.80 *$ & $1.68 *$ & $0.61 \mathrm{~ns}$ & $0.33 \mathrm{~ns}$ \\
\hline 1995 & $1.08 \mathrm{~ns}$ & $1.94 *$ & $2.80 * *$ & $2.86^{* *}$ & $3.42 * * *$ & $1.50 *$ & $0.70 \mathrm{~ns}$ & $1.24 \mathrm{~ns}$ & $1.12 \mathrm{~ns}$ & $0.76 \mathrm{~ns}$ & $0.13 \mathrm{~ns}$ & $0.10 \mathrm{~ns}$ \\
\hline 1996 & $2.50 * *$ & $4.14 * * *$ & $3.38 * * *$ & $2.74 * *$ & $1.65^{*}$ & 0.75 & $0.16 \mathrm{~ns}$ & $0.20 \mathrm{~ns}$ & $0.22 \mathrm{~ns}$ & $0.05 \mathrm{~ns}$ & $0.04 \mathrm{~ns}$ & $0.50 \mathrm{~ns}$ \\
\hline 1997 & $0.72 \mathrm{~ns}$ & $1.50 *$ & $1.58 *$ & $1.32 *$ & $1.15 \mathrm{~ns}$ & $1.31 *$ & $1.37 *$ & $1.98 *$ & $1.63 *$ & $0.80 \mathrm{~ns}$ & $0.42 \mathrm{~ns}$ & $0.50 \mathrm{~ns}$ \\
\hline 1998 & $1.17 \mathrm{~ns}$ & $1.42 *$ & $1.50 *$ & $1.23 \mathrm{~ns}$ & $1.10 \mathrm{~ns}$ & $1.1 \mathrm{~ns}$ & $0.2 \mathrm{~ns}$ & $0.46 \mathrm{~ns}$ & $0.41 \mathrm{~ns}$ & $0.33 \mathrm{~ns}$ & $0.25 \mathrm{~ns}$ & $0.72 \mathrm{~ns}$ \\
\hline 1999 & $1.73^{*}$ & $2.17 * *$ & $2.08 * *$ & $1.88 *$ & $1.37 *$ & $0.77 \mathrm{~ns}$ & $0.67 \mathrm{~ns}$ & $0.60 \mathrm{~ns}$ & $0.46 \mathrm{~ns}$ & $0.22 \mathrm{~ns}$ & $0.06 \mathrm{~ns}$ & $0.12 \mathrm{~ns}$ \\
\hline 2000 & $2.32 * *$ & $2.75 * *$ & $2.84 * *$ & $2.38 * *$ & $2.21 * *$ & $2.10 * *$ & $0.82 \mathrm{~ns}$ & $1.13 \mathrm{~ns}$ & $0.55 \mathrm{~ns}$ & $0.43 \mathrm{~ns}$ & $0.45 \mathrm{~ns}$ & $0.86 \mathrm{~ns}$ \\
\hline 2001 & $2.24 * *$ & $2.30 * *$ & $2.12 * *$ & $2.02 * *$ & $1.56^{*}$ & $1.88^{*}$ & $1.62 *$ & $1.90 *$ & $0.82 \mathrm{~ns}$ & $0.78 \mathrm{~ns}$ & $0.65 \mathrm{~ns}$ & $1.17 \mathrm{~ns}$ \\
\hline 2002 & $4.61 * * *$ & $5.86 * * *$ & $6.65 * * *$ & $6.46^{* * *}$ & $4.3^{* * *}$ & $2.62 * *$ & $0.73 \mathrm{~ns}$ & $0.74 \mathrm{~ns}$ & $0.68 \mathrm{~ns}$ & $0.11 \mathrm{~ns}$ & $0.03 \mathrm{~ns}$ & $0.3 \mathrm{~ns}$ \\
\hline
\end{tabular}


Trees Version définitive du manuscrit publié dans / Final version of the manuscript published in :

Trees - Structure \& Function, 2014, 28(5), 1289-1304

Centre region

\begin{tabular}{|c|c|c|c|c|c|c|c|c|c|c|c|}
\hline \multicolumn{6}{|c|}{ CVHD } & \multicolumn{6}{|l|}{ CVLD } \\
\hline \multicolumn{6}{|l|}{$d c$} & \multicolumn{6}{|l|}{$d c$} \\
\hline 0.3 & 0.4 & 0.5 & 0.6 & 0.7 & $\overline{0.8}$ & 0.3 & 0.4 & 0.5 & 0.6 & 0.7 & 0.8 \\
\hline
\end{tabular}

Annual ring

\begin{tabular}{|c|c|c|c|c|c|c|c|c|c|c|c|c|}
\hline 1986 & $1.0 \mathrm{~ns}$ & $0.23 \mathrm{~ns}$ & $0.14 \mathrm{~ns}$ & $0.27 \mathrm{~ns}$ & $0.36 \mathrm{~ns}$ & $0.43 \mathrm{~ns}$ & $0.14 \mathrm{~ns}$ & $0.20 \mathrm{~ns}$ & $0.07 \mathrm{~ns}$ & $0.1 \mathrm{~ns}$ & $0.12 \mathrm{~ns}$ & $0.13 \mathrm{~ns}$ \\
\hline 1987 & $0.17 \mathrm{~ns}$ & $0.18 \mathrm{~ns}$ & $0.60 \mathrm{~ns}$ & $0.50 \mathrm{~ns}$ & $0.87 \mathrm{~ns}$ & $0.18 \mathrm{~ns}$ & $0.47 \mathrm{~ns}$ & $0.40 \mathrm{~ns}$ & $0.28 \mathrm{~ns}$ & $0.29 \mathrm{~ns}$ & $0.64 \mathrm{~ns}$ & $0.14 \mathrm{~ns}$ \\
\hline 988 & $0.35 \mathrm{~ns}$ & $0.26 \mathrm{~ns}$ & $0.16 \mathrm{~ns}$ & $0.40 \mathrm{~ns}$ & $0.30 \mathrm{~ns}$ & $0.30 \mathrm{~ns}$ & $0.61 \mathrm{~ns}$ & $0.32 \mathrm{~ns}$ & $0.30 \mathrm{~ns}$ & $0.15 \mathrm{~ns}$ & $0.18 \mathrm{~ns}$ & $0.25 \mathrm{~ns}$ \\
\hline 1989 & $0.48 \mathrm{~ns}$ & $0.66 \mathrm{~ns}$ & $0.23 \mathrm{~ns}$ & $0.05 \mathrm{~ns}$ & $0.25 \mathrm{~ns}$ & $0.56 \mathrm{~ns}$ & $0.68 \mathrm{~ns}$ & $0.41 \mathrm{~ns}$ & $0.62 \mathrm{~ns}$ & $0.23 \mathrm{~ns}$ & $0.06 \mathrm{~ns}$ & $0.25 \mathrm{~ns}$ \\
\hline 990 & $1.60 *$ & $0.60 \mathrm{~ns}$ & $0.16 \mathrm{~ns}$ & $0.71 \mathrm{~ns}$ & $3.41 * * *$ & $0.60 \mathrm{~ns}$ & $0.52 \mathrm{~ns}$ & $0.24 \mathrm{~ns}$ & $0.22 \mathrm{~ns}$ & $0.04 \mathrm{~ns}$ & $0.53 \mathrm{~ns}$ & $0.98 \mathrm{~ns}$ \\
\hline 91 & $1.47 *$ & $0.60 \mathrm{~ns}$ & $0.42 \mathrm{~ns}$ & $0.56 \mathrm{~ns}$ & $0.38 \mathrm{~ns}$ & $0.88 \mathrm{~ns}$ & $0.32 \mathrm{~ns}$ & $0.54 \mathrm{~ns}$ & $0.56 \mathrm{~ns}$ & ns & $8 \mathrm{~ns}$ & $0.13 \mathrm{~ns}$ \\
\hline 992 & $0.31 \mathrm{~ns}$ & $0.08 \mathrm{~ns}$ & $\mathrm{~ns}$ & ns & 0.5 & ns & 0 & ns & $0.30 \mathrm{~ns}$ & ns & $5 \mathrm{~ns}$ & $6 \mathrm{~ns}$ \\
\hline 993 & $1.26 \mathrm{~ns}$ & $1.09 \mathrm{~ns}$ & $0.73 \mathrm{~ns}$ & $1.08 \mathrm{~ns}$ & $1.51^{*}$ & $0.90 \mathrm{~ns}$ & $0.33 \mathrm{~ns}$ & $0.30 \mathrm{~ns}$ & $0.28 \mathrm{~ns}$ & $0.15 \mathrm{~ns}$ & $0.10 \mathrm{~ns}$ & $0.08 \mathrm{~ns}$ \\
\hline 994 & $1.87 *$ & $1.77 *$ & $1.56^{*}$ & $1.0 \mathrm{~ns}$ & $0.91 \mathrm{~ns}$ & $2.18^{* *}$ & $0.03 \mathrm{~ns}$ & $0.02 \mathrm{~ns}$ & $0.04 \mathrm{~ns}$ & $0.02 \mathrm{~ns}$ & $0.001 \mathrm{~ns}$ & $0.006 \mathrm{~ns}$ \\
\hline 1995 & $2.70 * *$ & $2.45 * *$ & $1.32 *$ & $2.06 * *$ & $3.43 * * *$ & $1.44 *$ & $0.11 \mathrm{~ns}$ & $0.05 \mathrm{~ns}$ & $0.04 \mathrm{~ns}$ & $0.008 \mathrm{~ns}$ & $0.01 \mathrm{~ns}$ & $0.11 \mathrm{~ns}$ \\
\hline 1996 & $1.0 \mathrm{~ns}$ & $0.37 \mathrm{~ns}$ & $0.27 \mathrm{~ns}$ & $0.68 \mathrm{~ns}$ & $0.92 \mathrm{~ns}$ & $0.64 \mathrm{~ns}$ & $0.47 \mathrm{~ns}$ & $0.66 \mathrm{~ns}$ & $0.06 \mathrm{~ns}$ & $0.073 \mathrm{~ns}$ & $0.36 \mathrm{~ns}$ & $1.10 \mathrm{~ns}$ \\
\hline 1997 & $1.72 *$ & $0.42 \mathrm{~ns}$ & $0.35 \mathrm{~ns}$ & $0.83 \mathrm{~ns}$ & $1.70^{*}$ & $1.64 *$ & $0.05 \mathrm{~ns}$ & $0.03 \mathrm{~ns}$ & $0.03 \mathrm{~ns}$ & $0.006 \mathrm{~ns}$ & $0.005 \mathrm{~ns}$ & $0.02 \mathrm{~ns}$ \\
\hline 1998 & $0.74 \mathrm{~ns}$ & $0.74 \mathrm{~ns}$ & $0.77 \mathrm{~ns}$ & $0.60 \mathrm{~ns}$ & $0.85 \mathrm{~ns}$ & $0.80 \mathrm{~ns}$ & $0.43 \mathrm{~ns}$ & $0.16 \mathrm{~ns}$ & $0.23 \mathrm{~ns}$ & $0.20 \mathrm{~ns}$ & $0.21 \mathrm{~ns}$ & $0.40 \mathrm{~ns}$ \\
\hline 1999 & $0.74 \mathrm{~ns}$ & $0.28 \mathrm{~ns}$ & $0.15 \mathrm{~ns}$ & $0.10 \mathrm{~ns}$ & $0.40 \mathrm{~ns}$ & $1.20 \mathrm{~ns}$ & $0.08 \mathrm{~ns}$ & $0.12 \mathrm{~ns}$ & $0.16 \mathrm{~ns}$ & $0.11 \mathrm{~ns}$ & $0.06 \mathrm{~ns}$ & $0.18 \mathrm{~ns}$ \\
\hline 0 & $1.25 \mathrm{~ns}$ & $1.16 \mathrm{~ns}$ & $1.14 \mathrm{~ns}$ & $1.44 *$ & $2.12 * *$ & $1.63^{*}$ & $0.06 \mathrm{~ns}$ & $0.23 \mathrm{~ns}$ & $0.15 \mathrm{~ns}$ & $0.09 \mathrm{~ns}$ & $0.11 \mathrm{~ns}$ & $0.09 \mathrm{~ns}$ \\
\hline 00 & $0.71 \mathrm{~ns}$ & $0.46 \mathrm{~ns}$ & $0.50 \mathrm{~ns}$ & $0.67 \mathrm{~ns}$ & $1.45^{*}$ & $1.78 *$ & $0.02 \mathrm{r}$ & $0.008 \mathrm{~ns}$ & $0.04 \mathrm{~ns}$ & $0.13 \mathrm{~ns}$ & $0.06 \mathrm{~ns}$ & $0.04 \mathrm{~ns}$ \\
\hline 002 & $4.00 * * *$ & $4.63 * * *$ & $3.70 * * *$ & $3.05 * * *$ & $3.06^{* * *}$ & $1.42 *$ & $0.08 \mathrm{~ns}$ & $0.09 \mathrm{~ns}$ & $0.03 \mathrm{~ns}$ & $0.03 \mathrm{~ns}$ & $0.06 \mathrm{~ns}$ & $0.57 \mathrm{~ns}$ \\
\hline
\end{tabular}

Centre region

PHD

$d c$

0.3

0.4

0.5

0.6

0.7

0.8

Annual ring

\begin{tabular}{|c|c|c|c|c|c|c|}
\hline 1986 & $0.90 \mathrm{~ns}$ & $0.54 \mathrm{~ns}$ & $0.58 \mathrm{~ns}$ & $0.66 \mathrm{~ns}$ & $0.77 \mathrm{~ns}$ & $0.63 \mathrm{~ns}$ \\
\hline 1987 & $0.70 \mathrm{~ns}$ & $1.02 \mathrm{~ns}$ & $0.90 \mathrm{~ns}$ & $0.81 \mathrm{~ns}$ & $0.15 \mathrm{~ns}$ & $0.28 \mathrm{~ns}$ \\
\hline 1988 & $0.63 \mathrm{~ns}$ & $0.60 \mathrm{~ns}$ & $0.55 \mathrm{~ns}$ & $0.46 \mathrm{~ns}$ & $0.36 \mathrm{~ns}$ & $0.37 \mathrm{~ns}$ \\
\hline 1989 & $0.40 \mathrm{~ns}$ & $0.23 \mathrm{~ns}$ & $0.1 \mathrm{~ns}$ & $0.08 \mathrm{~ns}$ & $0.34 \mathrm{~ns}$ & $0.54 \mathrm{~ns}$ \\
\hline 1990 & $0.78 \mathrm{~ns}$ & $0.83 \mathrm{~ns}$ & $1.09 \mathrm{~ns}$ & $2.61 * *$ & $3.04 * * *$ & $1.89 *$ \\
\hline 1991 & $1.43 *$ & $1.05 \mathrm{~ns}$ & $0.75 \mathrm{~ns}$ & $0.92 \mathrm{~ns}$ & $1.35^{*}$ & $1.22 \mathrm{~ns}$ \\
\hline 1992 & $0.58 \mathrm{~ns}$ & $0.63 \mathrm{~ns}$ & $0.80 \mathrm{~ns}$ & $0.54 \mathrm{~ns}$ & $0.63 \mathrm{~ns}$ & $0.80 \mathrm{~ns}$ \\
\hline 1993 & $1.05 \mathrm{~ns}$ & $0.80 \mathrm{~ns}$ & $0.54 \mathrm{~ns}$ & $1.0 \mathrm{~ns}$ & $0.60 \mathrm{~ns}$ & $1.08 \mathrm{~ns}$ \\
\hline 1994 & $1.50 *$ & $1.18 \mathrm{~ns}$ & $0.78 \mathrm{~ns}$ & $0.56 \mathrm{~ns}$ & $1.26 \mathrm{~ns}$ & 1.92 \\
\hline 1995 & $1.58 *$ & $0.98 \mathrm{~ns}$ & $0.68 \mathrm{~ns}$ & $0.77 \mathrm{~ns}$ & $2.27 * *$ & $3.40 * * *$ \\
\hline 1996 & $0.46 \mathrm{~ns}$ & $0.54 \mathrm{~ns}$ & $1.32 *$ & $2.81 * *$ & $3.76^{* * *}$ & $2.61 * *$ \\
\hline 1997 & $1.93 *$ & $1.23 \mathrm{~ns}$ & $1.34 *$ & $1.80 *$ & $1.93 *$ & $1.70 *$ \\
\hline 1998 & $1.45^{*}$ & $1.50 *$ & $1.97 *$ & $2.24 * *$ & $2.51 * *$ & $1.47 *$ \\
\hline 1999 & $1.15 \mathrm{~ns}$ & $1.12 \mathrm{~ns}$ & $1.56^{*}$ & $2.06 * *$ & $2.92 * *$ & $3.31 * * *$ \\
\hline 2000 & $1.67 *$ & $1.52 *$ & $2.92 * *$ & $3.75 * * *$ & $3.72 * * *$ & $2.16 * *$ \\
\hline 2001 & $2.06^{* *}$ & $2.20 * *$ & $3.9 * * *$ & $4.20 * * *$ & $3.96 * * *$ & $2.38 * *$ \\
\hline 2002 & $1.05 \mathrm{~ns}$ & $1.40^{*}$ & $1.96^{*}$ & $3.97 * * *$ & $7.0 * * *$ & $6.50 * * *$ \\
\hline
\end{tabular}

$d \mathrm{c}$ density criterion, $\log 10$ of associated probabilities, $n s$ not significant

$(* * *)$ for $p<0.001,(* *)$ for $p<0.01$ and $(*)$ for $p<0.05$ 
Version définitive du manuscrit publié dans / Final version of the manuscript published in :

Trees-Structure \& Function, 2014, 28(5), 1289-1304

Table $5 \log 10$ of associated probabilities of observed mean differences between surviving and dead trees under $\mathrm{H}_{0}=$ no difference for original variables calculated at the annual ring level in the Midi-Pyrénées region

\begin{tabular}{llllll} 
Midi-pyrenees region & & & & \\
\hline MHD & & & & \\
\hline$d c$ & & & & & \\
\hline 0.3 & 0.4 & 0.5 & 0.6 & 0.7 & 0.8
\end{tabular}

\begin{tabular}{llllll} 
MLD & & & & & \\
\hline$d c$ & & & & & \\
\hline 0.3 & 0.4 & 0.5 & 0.6 & 0.7 & 0.8 \\
\hline
\end{tabular}

Annual ring

\begin{tabular}{|c|c|c|c|c|c|c|c|c|c|c|c|c|}
\hline 1993 & $2.17^{* *}$ & $1.81^{*}$ & $1.34 *$ & $0.99 \mathrm{~ns}$ & $1.0 \mathrm{~ns}$ & $0.71 \mathrm{~ns}$ & $2.35^{* *}$ & $1.50^{*}$ & $0.92 \mathrm{~ns}$ & $0.51 \mathrm{~ns}$ & $1.23 \mathrm{~ns}$ & $1.94 *$ \\
\hline 1994 & $1.09 \mathrm{~ns}$ & $1.33^{*}$ & $1.09 \mathrm{~ns}$ & $0.95 \mathrm{~ns}$ & $0.56 \mathrm{~ns}$ & $1.09 \mathrm{~ns}$ & $2.40 * *$ & $2.07 * *$ & $1.24 \mathrm{~ns}$ & $1.0 \mathrm{~ns}$ & $1.52 *$ & $1.16 \mathrm{~ns}$ \\
\hline 1995 & $0.64 \mathrm{~ns}$ & $0.85 \mathrm{~ns}$ & $0.90 \mathrm{~ns}$ & $0.64 \mathrm{~ns}$ & $0.27 \mathrm{~ns}$ & $0.28 \mathrm{~ns}$ & $3.47 * * *$ & $2.80 * *$ & $2.58^{* *}$ & $1.45^{*}$ & $1.32 *$ & $1.70^{*}$ \\
\hline 1996 & $1.24 \mathrm{~ns}$ & $1.60^{*}$ & $1.86^{*}$ & $1.33 *$ & $1.14 \mathrm{~ns}$ & $0.82 \mathrm{~ns}$ & $3.94 * * *$ & $3.60^{* * * *}$ & $2.97 * *$ & $1.54 *$ & $1.12 \mathrm{~ns}$ & $0.14 \mathrm{~ns}$ \\
\hline 1997 & $0.85 \mathrm{~ns}$ & $1.42^{*}$ & $1.43^{*}$ & $1.00 \mathrm{~ns}$ & $0.81 \mathrm{~ns}$ & $1.08 \mathrm{~ns}$ & $4.47 * * *$ & $4.22^{* * * *}$ & $2.62 * *$ & $0.92 \mathrm{~ns}$ & $0.86 \mathrm{~ns}$ & $0.25 \mathrm{~ns}$ \\
\hline 1998 & $1.45^{*}$ & $2.12^{* * *}$ & $2.33 * *$ & $2.07 * *$ & $1.74 *$ & $1.00 \mathrm{~ns}$ & $4.08 * * *$ & $4.00^{* * *}$ & $2.57 * *$ & $1.44 *$ & $0.55 \mathrm{~ns}$ & $0.87 \mathrm{~ns}$ \\
\hline 1999 & $1.46^{*}$ & $2.13^{* *}$ & $2.54 * *$ & $2.95 * *$ & $2.67 * *$ & $1.90^{*}$ & $3.80 * * *$ & $3.47^{* * *}$ & $2.75^{* *}$ & $1.53^{*}$ & $0.72 \mathrm{~ns}$ & $0.19 \mathrm{~ns}$ \\
\hline 2000 & $2.63^{* *}$ & $3.23^{* * *}$ & $3.36 * * *$ & $3.03^{* * *}$ & $2.90 * *$ & $1.26 \mathrm{~ns}$ & $2.20 * *$ & $2.03^{* *}$ & $1.05 \mathrm{~ns}$ & $0.4 \mathrm{~ns}$ & $0.17 \mathrm{~ns}$ & $0.11 \mathrm{~ns}$ \\
\hline 2001 & $3.20^{* * *}$ & $4.17^{* * *}$ & $4^{* * *}$ & $3.62 * * *$ & $2.26^{* *}$ & $1.76^{*}$ & $3.05 * * *$ & $2.45^{* *}$ & $1.53^{*}$ & $1.0 \mathrm{~ns}$ & $0.64 \mathrm{~ns}$ & $1.11 \mathrm{~ns}$ \\
\hline 2002 & $0.60 \mathrm{~ns}$ & $1.25 \mathrm{~ns}$ & $1.18 \mathrm{~ns}$ & $1.68 *$ & $1.74 *$ & $2.54 * *$ & $3.75 * * *$ & $3.60^{* * *}$ & $4.11 * * *$ & $1.76^{*}$ & $2.04 *$ & $0.17 \mathrm{~ns}$ \\
\hline
\end{tabular}

Midi-pyrenees region

CVHD

\begin{tabular}{lllllll}
\hline$d c$ & & & & & & \\
\hline 0.3 & 0.4 & 0.5 & 0.6 & 0.7 & 0.8
\end{tabular}

CVLD

$d c$

$0.3 \quad 0.4$

Annual ring

$\begin{array}{lllllllllllll}1993 & 0.22 \mathrm{~ns} & 0.12 \mathrm{~ns} & 0.19 \mathrm{~ns} & 0.61 \mathrm{~ns} & 1.31 \mathrm{~ns} & 0.70 \mathrm{~ns} & 0.0008 \mathrm{~ns} & 0.0001 \mathrm{~ns} & 0.0005 \mathrm{~ns} & 0.005 \mathrm{~ns} & 0.04 \mathrm{~ns} & 0.001 \mathrm{~ns} \\ 1994 & 0.82 \mathrm{~ns} & 0.31 \mathrm{~ns} & 0.60 \mathrm{~ns} & 0.70 \mathrm{~ns} & 1.20 \mathrm{~ns} & 1.11 \mathrm{~ns} & 0.005 \mathrm{~ns} & 0.002 \mathrm{~ns} & 0.002 \mathrm{~ns} & 0.13 \mathrm{~ns} & 0.0004 \mathrm{~ns} & 0.002 \mathrm{~ns} \\ 1995 & 0.80 \mathrm{~ns} & 0.42 \mathrm{~ns} & 0.20 \mathrm{~ns} & 0.45 \mathrm{~ns} & 0.40 \mathrm{~ns} & 0.24 \mathrm{~ns} & 7.7 \mathrm{e}-05 \mathrm{~ns} & 7.8 \mathrm{e}-05 \mathrm{~ns} & 0.002 \mathrm{~ns} & 0.0002 \mathrm{~ns} & 0.001 \mathrm{~ns} & 0.008 \mathrm{~ns} \\ 1996 & 0.69 \mathrm{~ns} & 0.42 \mathrm{~ns} & 0.14 \mathrm{~ns} & 0.22 \mathrm{~ns} & 0.34 \mathrm{~ns} & 0.50 \mathrm{~ns} & 2.5 \mathrm{e}-05 \mathrm{~ns} & 4.3 \mathrm{e}-05 \mathrm{~ns} & 0.0002 \mathrm{~ns} & 0.0002 \mathrm{~ns} & 0.0004 \mathrm{~ns} & 0.008 \mathrm{~ns} \\ 1997 & 1.81^{*} & 0.66 \mathrm{~ns} & 0.50 \mathrm{~ns} & 0.21 \mathrm{~ns} & 0.62 \mathrm{~ns} & 1.34^{*} & 4.4 \mathrm{e}-05 \mathrm{~ns} & 9.4 \mathrm{e}-05 \mathrm{~ns} & 2.4 \mathrm{e}-05 \mathrm{~ns} & 0.0001 \mathrm{~ns} & 0.0008 \mathrm{~ns} & 0.001 \mathrm{~ns} \\ 1998 & 1.72^{*} & 0.94 \mathrm{~ns} & 1.06 \mathrm{~ns} & 1.28 \mathrm{~ns} & 1.30^{*} & 0.83 \mathrm{~ns} & 5.9 \mathrm{e}-05 \mathrm{~ns} & 0.0004 \mathrm{~ns} & 0.0001 \mathrm{~ns} & 0.0002 \mathrm{~ns} & 5.6 \mathrm{e}-05 \mathrm{~ns} & 0.014 \mathrm{~ns} \\ 1999 & 2.94^{* *} & 2.40^{* *} & 1.87^{*} & 1.79^{*} & 1.57^{*} & 2.06^{* *} & 0.0004 \mathrm{~ns} & 0.001 \mathrm{~ns} & 0.0008 \mathrm{~ns} & 0.0002 \mathrm{~ns} & 0.0005 \mathrm{~ns} & 0.002 \mathrm{~ns} \\ 2000 & 2.58^{* *} & 2.26^{* *} & 2.31^{* *} & 1.93^{*} & 2.14^{* *} & 1.62^{*} & 0.007 \mathrm{~ns} & 0.006 \mathrm{~ns} & 0.002 \mathrm{~ns} & 0.001 \mathrm{~ns} & 0.01 \mathrm{~ns} & 0.093 \mathrm{~ns} \\ 2001 & 3.24^{* * *} & 1.50^{*} & 2.22^{* *} & 1.60^{*} & 1.80^{*} & 2.36^{* *} & 0.0002 \mathrm{~ns} & 0.0005 \mathrm{~ns} & 0.0007 \mathrm{~ns} & 0.002 \mathrm{~ns} & 0.002 \mathrm{~ns} & 0.004 \mathrm{~ns} \\ 2002 & 3.05^{* * *} & 3.32^{* * *} & 3.80^{* * *} & 2.86^{* *} & 2.20^{* *} & 2.90^{* *} & 0.0005 \mathrm{~ns} & 0.0001 \mathrm{~ns} & 0.001 \mathrm{~ns} & 0.03 \mathrm{~ns} & 0.0008 \mathrm{~ns} & 0.002 \mathrm{~ns}\end{array}$

Midi-pyrenees region

PHD

$d c$

0.3

0.4

0.5

0.6

0.7

0.8

Annual ring

1993

1994

$1.37 *$

$1.78^{*}$

$0.97 \mathrm{~ns}$

$0.85 \mathrm{~ns}$

$1.11 \mathrm{~ns}$

$0.93 \mathrm{~ns}$

$0.72 \mathrm{~ns}$

$0.45 \mathrm{~ns}$

$0.80 \mathrm{~ns}$

$0.75 \mathrm{~ns}$

0.84 ns

$1.18 \mathrm{~ns}$

$0.81 \mathrm{~ns}$

$0.87 \mathrm{~ns}$

$1.91 *$

$2.72 * *$

$2.07 * *$

$1.7 *$

$2.07 * *$
$1.25 \mathrm{~ns}$
$0.87 \mathrm{~ns}$
$0.71 \mathrm{~ns}$
$0.60 \mathrm{~ns}$
$0.96 \mathrm{~ns}$
$0.84 \mathrm{~ns}$
$1.36 *$
$2.80 * *$
$1.07 \mathrm{~ns}$

$2.7 * *$

$1.25 \mathrm{~ns}$

$1.09 \mathrm{~ns}$

$1.09 \mathrm{~ns}$

$1.03 \mathrm{~ns}$

$1.23 \mathrm{~ns}$

$1.0 \mathrm{~ns}$

$1.72 *$

$2.74 * *$

0.48 ns

1.91*

0.90 ns

$0.68 \mathrm{~ns}$

$0.54 \mathrm{~ns}$

$1.33^{*}$

$1.02 \mathrm{~ns}$

$1.76^{*}$

$0.95 \mathrm{~ns}$

$0.74 \mathrm{~ns}$

1.90*

$1.36 *$

2.36 **

2.70**

$1.82 *$

3.32***

$2.94 * *$

2002

$1.07 \mathrm{~ns}$

$0.75 \mathrm{~ns}$

$1.93 *$

$d$ c density criterion, $\log 10$ of associated probabilities, $n s$ not significant

$(* * *)$ for $p<0.001,(* *)$ for $p<0.01$ and $(*)$ for $p<0.05$ 
Trees Version définitive du manuscrit publié dans / Final version of the manuscript published in :

Trees - Structure \& Function, 2014, 28(5), 1289-1304

Table $6 \log 10$ of associated probabilities of observed mean differences between surviving and dead trees under $\mathrm{H}_{0}=$ no difference for original variables calculated at annual ring level in the Burgundy region

\begin{tabular}{llllll} 
Burgundy Region & & & & \\
\hline MHD & & & & \\
\hline$d c$ & & & & & \\
\hline 0.3 & 0.4 & 0.5 & 0.6 & 0.7 & 0.8
\end{tabular}

MLD

$d c$

\begin{tabular}{llllll}
\hline 0.3 & 0.4 & 0.5 & 0.6 & 0.7 & 0.8
\end{tabular}

Annual ring

\begin{tabular}{|c|c|c|c|c|c|c|c|c|c|c|c|c|}
\hline 1993 & $0.85 \mathrm{~ns}$ & $0.88 \mathrm{~ns}$ & $0.90 \mathrm{~ns}$ & $1.07 \mathrm{~ns}$ & $0.7 \mathrm{~ns}$ & $0.66 \mathrm{~ns}$ & $0.60 \mathrm{~ns}$ & $0.47 \mathrm{~ns}$ & $0.22 \mathrm{~ns}$ & $0.30 \mathrm{~ns}$ & $0.03 \mathrm{~ns}$ & $0.20 \mathrm{~ns}$ \\
\hline 1994 & $0.38 \mathrm{~ns}$ & $0.24 \mathrm{~ns}$ & $0.30 \mathrm{~ns}$ & $0.40 \mathrm{~ns}$ & $0.35 \mathrm{~ns}$ & $0.56 \mathrm{~ns}$ & $0.70 \mathrm{~ns}$ & $0.40 \mathrm{~ns}$ & $0.73 \mathrm{~ns}$ & $0.81 \mathrm{~ns}$ & $1.13 \mathrm{~ns}$ & $0.66 \mathrm{~ns}$ \\
\hline 1995 & $0.24 \mathrm{~ns}$ & $0.39 \mathrm{~ns}$ & $0.60 \mathrm{~ns}$ & $0.42 \mathrm{~ns}$ & $0.30 \mathrm{~ns}$ & $0.32 \mathrm{~ns}$ & $1.76^{*}$ & $1.54 *$ & $1.34 *$ & $0.97 \mathrm{~ns}$ & $1.17 \mathrm{~ns}$ & $1.14 \mathrm{~ns}$ \\
\hline 1996 & $0.34 \mathrm{~ns}$ & $0.55 \mathrm{~ns}$ & $0.53 \mathrm{~ns}$ & $0.31 \mathrm{~ns}$ & $0.33 \mathrm{~ns}$ & $0.40 \mathrm{~ns}$ & $2.70^{* *}$ & $2.60 * *$ & $2.07^{* *}$ & $0.98 \mathrm{~ns}$ & $0.75 \mathrm{~ns}$ & $1.09 \mathrm{~ns}$ \\
\hline 1997 & $0.24 \mathrm{~ns}$ & $0.36 \mathrm{~ns}$ & $0.36 \mathrm{~ns}$ & $0.46 \mathrm{~ns}$ & $0.45 \mathrm{~ns}$ & $0.34 \mathrm{~ns}$ & $2.85^{* *}$ & $2.09 * *$ & $2.40^{* *}$ & $1.87 *$ & $1.15 \mathrm{~ns}$ & $1.23 \mathrm{~ns}$ \\
\hline 1998 & $1.57^{*}$ & $1.34^{*}$ & $1.30^{*}$ & $1.54 *$ & $0.83 \mathrm{~ns}$ & $0.88 \mathrm{~ns}$ & $2.26^{* *}$ & $1.75^{*}$ & $1.40^{*}$ & $1.70^{*}$ & $1.27 \mathrm{~ns}$ & $0.61 \mathrm{~ns}$ \\
\hline 1999 & $0.51 \mathrm{~ns}$ & $0.74 \mathrm{~ns}$ & $0.78 \mathrm{~ns}$ & $0.85 \mathrm{~ns}$ & $0.30 \mathrm{~ns}$ & $0.33 \mathrm{~ns}$ & $4.08^{* * *}$ & $4.17^{* * *}$ & $2.96^{*}$ & $2.48^{* *}$ & $0.32 \mathrm{~ns}$ & $0.35 \mathrm{~ns}$ \\
\hline 2000 & $0.75 \mathrm{~ns}$ & $0.88 \mathrm{~ns}$ & $0.81 \mathrm{~ns}$ & $0.83 \mathrm{~ns}$ & $0.44 \mathrm{~ns}$ & $0.76 \mathrm{~ns}$ & $2.48^{* *}$ & $2.27 * *$ & $1.79 *$ & $1.50 *$ & $0.64 \mathrm{~ns}$ & $0.74 \mathrm{~ns}$ \\
\hline 2001 & $1.08 \mathrm{~ns}$ & $1.04 \mathrm{~ns}$ & $0.84 \mathrm{~ns}$ & $0.75 \mathrm{~ns}$ & $0.64 \mathrm{~ns}$ & $0.78 \mathrm{~ns}$ & $1.75^{*}$ & $1.48^{*}$ & $0.92 \mathrm{~ns}$ & $0.85 \mathrm{~ns}$ & $0.60 \mathrm{~ns}$ & $0.50 \mathrm{~ns}$ \\
\hline 2002 & $0.85 \mathrm{~ns}$ & $1.0 \mathrm{~ns}$ & $1.09 \mathrm{~ns}$ & $1.04 \mathrm{~ns}$ & $0.66 \mathrm{~ns}$ & $1.63^{*}$ & $1.80 *$ & $1.33^{*}$ & $0.97 \mathrm{~ns}$ & $0.82 \mathrm{~ns}$ & $0.30 \mathrm{~ns}$ & $0.22 \mathrm{~ns}$ \\
\hline
\end{tabular}

Burgundy region

CVHD

\section{$d c$}

0.3
$0.4 \quad 0.5$

0.5

0.5

0.7

Annual ring

\begin{tabular}{lllllllllllll}
1993 & $0.71 \mathrm{~ns}$ & $0.84 \mathrm{~ns}$ & $1.08 \mathrm{~ns}$ & $0.73 \mathrm{~ns}$ & $0.60 \mathrm{~ns}$ & $0.76 \mathrm{~ns}$ & $0.04 \mathrm{~ns}$ & $0.04 \mathrm{~ns}$ & $0.05 \mathrm{~ns}$ & $0.10 \mathrm{~ns}$ & $0.05 \mathrm{~ns}$ & $0.03 \mathrm{~ns}$ \\
1994 & $0.31 \mathrm{~ns}$ & $0.85 \mathrm{~ns}$ & $0.77 \mathrm{~ns}$ & $0.56 \mathrm{~ns}$ & $0.47 \mathrm{~ns}$ & $0.87 \mathrm{~ns}$ & $0.04 \mathrm{~ns}$ & $0.04 \mathrm{~ns}$ & $0.32 \mathrm{~ns}$ & $0.30 \mathrm{~ns}$ & $0.14 \mathrm{~ns}$ & $0.01 \mathrm{~ns}$ \\
1995 & $1.18 \mathrm{~ns}$ & $1.00 \mathrm{~ns}$ & $0.62 \mathrm{~ns}$ & $0.75 \mathrm{~ns}$ & $0.40 \mathrm{~ns}$ & $0.44 \mathrm{~ns}$ & $0.005 \mathrm{~ns}$ & $0.005 \mathrm{~ns}$ & $0.024 \mathrm{~ns}$ & $0.008 \mathrm{~ns}$ & $0.005 \mathrm{~ns}$ & $0.02 \mathrm{~ns}$ \\
1996 & $0.80 \mathrm{~ns}$ & $0.34 \mathrm{~ns}$ & $0.33 \mathrm{~ns}$ & $0.78 \mathrm{~ns}$ & $0.84 \mathrm{~ns}$ & $0.43 \mathrm{~ns}$ & $0.002 \mathrm{~ns}$ & $0.003 \mathrm{~ns}$ & $0.001 \mathrm{~ns}$ & $0.0009 \mathrm{~ns}$ & $0.006 \mathrm{~ns}$ & $0.12 \mathrm{~ns}$ \\
1997 & $0.81 \mathrm{~ns}$ & $0.50 \mathrm{~ns}$ & $0.58 \mathrm{~ns}$ & $0.31 \mathrm{~ns}$ & $0.53 \mathrm{~ns}$ & $0.32 \mathrm{~ns}$ & $0.0002 \mathrm{~ns}$ & $0.0001 \mathrm{~ns}$ & $0.003 \mathrm{~ns}$ & $0.001 \mathrm{~ns}$ & $0.001 \mathrm{~ns}$ & $0.0004 \mathrm{~ns}$ \\
1998 & $0.86 \mathrm{~ns}$ & $1.48^{*}$ & $1.80^{*}$ & $1.63^{*}$ & $1.16 \mathrm{~ns}$ & $0.96 \mathrm{~ns}$ & $0.003 \mathrm{~ns}$ & $0.0009 \mathrm{~ns}$ & $0.01 \mathrm{~ns}$ & $0.006 \mathrm{~ns}$ & $0.001 \mathrm{~ns}$ & $6.5 \mathrm{e}-05 \mathrm{~ns}$ \\
1999 & $1.02 \mathrm{~ns}$ & $0.30 \mathrm{~ns}$ & $0.40 \mathrm{~ns}$ & $0.25 \mathrm{~ns}$ & $0.55 \mathrm{~ns}$ & $0.77 \mathrm{~ns}$ & $5.0 \mathrm{e}-05 \mathrm{~ns}$ & $0.0004 \mathrm{~ns}$ & $6.9 \mathrm{e}-05 \mathrm{~ns}$ & $0.0002 \mathrm{~ns}$ & $3.4 \mathrm{e}-05 \mathrm{~ns}$ & $0.05 \mathrm{~ns}$ \\
2000 & $0.66 \mathrm{~ns}$ & $0.28 \mathrm{~ns}$ & $0.45 \mathrm{~ns}$ & $0.45 \mathrm{~ns}$ & $0.23 \mathrm{~ns}$ & $0.55 \mathrm{~ns}$ & $2.2 \mathrm{e}-05 \mathrm{~ns}$ & $0.0002 \mathrm{~ns}$ & $0.0008 \mathrm{~ns}$ & $0.0004 \mathrm{~ns}$ & $0.0006 \mathrm{~ns}$ & $0.06 \mathrm{~ns}$ \\
2001 & $0.27 \mathrm{~ns}$ & $0.23 \mathrm{~ns}$ & $0.77 \mathrm{~ns}$ & $0.55 \mathrm{~ns}$ & $0.40 \mathrm{~ns}$ & $0.97 \mathrm{~ns}$ & $0.005 \mathrm{~ns}$ & $0.003 \mathrm{~ns}$ & $0.001 \mathrm{~ns}$ & $0.024 \mathrm{~ns}$ & $0.02 \mathrm{~ns}$ & $0.11 \mathrm{~ns}$ \\
2002 & $0.83 \mathrm{~ns}$ & $1.0 \mathrm{~ns}$ & $1.22 \mathrm{~ns}$ & $0.83 \mathrm{~ns}$ & $0.36 \mathrm{~ns}$ & $1.38^{*}$ & $0.001 \mathrm{~ns}$ & $0.0005 \mathrm{~ns}$ & $0.002 \mathrm{~ns}$ & $0.005 \mathrm{~ns}$ & $0.02 \mathrm{~ns}$ & $0.02 \mathrm{~ns}$ \\
\hline
\end{tabular}

Burgundy region

PHD

$d c$

0.3

Annual ring

1993

1994

1995

1996

1997

1998

1999

2000

2001

2002

$\begin{array}{ll}0.27 \mathrm{~ns} & 0.30 \mathrm{~ns} \\ 0.53 \mathrm{~ns} & 0.90 \mathrm{~ns} \\ 0.98 \mathrm{~ns} & 0.73 \mathrm{~ns} \\ 0.70 \mathrm{~ns} & 0.48 \mathrm{~ns} \\ 1.07 \mathrm{~ns} & 0.90 \mathrm{~ns} \\ 1.74^{*} & 2.70^{* *} \\ 1.27 \mathrm{~ns} & 0.81 \mathrm{~ns} \\ 1.56^{*} & 1.18 \mathrm{~ns} \\ 1.28 \mathrm{~ns} & 1.27 \mathrm{~ns} \\ 0.51 \mathrm{~ns} & 0.40 \mathrm{~ns}\end{array}$

$0.56 \mathrm{~ns}$

$0.61 \mathrm{~ns}$

$0.61 \mathrm{~ns}$

$0.52 \mathrm{~ns}$

$0.67 \mathrm{~ns}$

2.80 **

$0.76 \mathrm{~ns}$

$1.18 \mathrm{~ns}$

$1.58^{*}$

$0.46 \mathrm{~ns}$

CVLD

$\mathrm{dc}$

0.4

0.5

0.6

0.7

0.8

$d \mathrm{c}$ density criterion, $\log 10$ of associated probabilities, $n s$ not significant

(***) for $p<0.001,(* *)$ for $p<0.01$ and $(*)$ for $p<0.05$

$\begin{array}{lll}0.35 \mathrm{~ns} & 1.08 \mathrm{~ns} & 0.84 \mathrm{~ns} \\ 0.43 \mathrm{~ns} & 0.32 \mathrm{~ns} & 0.44 \mathrm{~ns} \\ 0.72 \mathrm{~ns} & 0.60 \mathrm{~ns} & 0.24 \mathrm{~ns} \\ 0.63 \mathrm{~ns} & 0.50 \mathrm{~ns} & 0.09 \mathrm{~ns} \\ 0.39 \mathrm{~ns} & 0.50 \mathrm{~ns} & 0.28 \mathrm{~ns} \\ 1.97^{*} & 0.93 \mathrm{~ns} & 1.37 * \\ 0.62 \mathrm{~ns} & 1.10 \mathrm{~ns} & 0.77 \mathrm{~ns} \\ 0.84 \mathrm{~ns} & 1.0 \mathrm{~ns} & 0.97 \mathrm{~ns} \\ 0.97 \mathrm{~ns} & 0.90 \mathrm{~ns} & 0.97 \mathrm{~ns} \\ 0.50 \mathrm{~ns} & 0.48 \mathrm{~ns} & 1.13 \mathrm{~ns} \\ \end{array}$


Version définitive du manuscrit publié dans / Final version of the manuscript published in :

Trees - Structure \& Function, 2014, 28(5), 1289-1304

Table 7 Pearson's coefficient of correlation between original ring variables and conventional ring variables

\begin{tabular}{|c|c|c|c|c|c|c|c|c|}
\hline Variables & RW & MRD & EWD & LWD & MID & MAD & SEQ & EWP \\
\hline MHD $0.3 \mathrm{~d} f=2916$ & $-0.041 *$ & $0.42 * * *$ & $-0.15^{* * *}$ & $0.62 * * *$ & $-0.11 * * *$ & $0.23^{* * *}$ & $-0.062 * * *$ & $-0.36^{* * *}$ \\
\hline MHD $0.4 \mathrm{~d} f=2912$ & $-0.093 * * *$ & $0.57 * * *$ & $0.067 * * *$ & $0.84 * * *$ & $0.15 * * *$ & $0.30 * * *$ & $0.15 * * *$ & $-0.30 * * *$ \\
\hline MHD $0.5 \mathrm{~d} f=2920$ & $-0.078 * * *$ & $0.56^{* * *}$ & $0.15 * * *$ & $0.89 * * *$ & $0.23 * * *$ & $0.33 * * *$ & $0.19 * * *$ & $-0.20 * * *$ \\
\hline MHD $0.6 \mathrm{~d} f=2906$ & $-0.057 * *$ & $0.51 * * *$ & $0.22 * * *$ & $0.88 * * *$ & $0.27 * * *$ & $0.34 * * *$ & $0.22 * * *$ & $-0.086 * * *$ \\
\hline MHD $0.7 \mathrm{~d} f=2865$ & $-0.04 *$ & $0.44 * * *$ & $0.28 * * *$ & $0.73 * * *$ & $0.31 * * *$ & $0.31 * * *$ & $0.25^{* * *}$ & $-0.024 \mathrm{~ns}$ \\
\hline MHD $0.8 \mathrm{~d} f=2728$ & $-0.012 \mathrm{~ns}$ & $0.40 * * *$ & $0.30 * * *$ & $0.62 * * *$ & $0.31 * * *$ & $0.27 * * *$ & $0.24 * * *$ & $-0.026 \mathrm{~ns}$ \\
\hline MLD $0.3 \mathrm{~d} f=2937$ & $-0.11 * * *$ & $0.38 * * *$ & $0.50 * * *$ & $0.11 * * *$ & $0.53 * * *$ & $0.036 \mathrm{~ns}$ & $0.48 * * *$ & $-0.19 * * *$ \\
\hline MLD $0.4 \mathrm{~d} f=2937$ & $-0.11 * * *$ & $0.43 * * *$ & $0.60 * * *$ & $0.12 * * *$ & $0.60 * * *$ & $0.043 *$ & $0.56 * * *$ & $-0.21 * * *$ \\
\hline MLD $0.5 \mathrm{~d} f=2937$ & $-0.078 * * *$ & $0.43 * * *$ & $0.68 * * *$ & $0.069 * * *$ & $0.66^{* * *}$ & $0.036 \mathrm{~ns}$ & $0.61 * * *$ & $-0.18^{* * *}$ \\
\hline MLD $0.6 \mathrm{~d} f=2938$ & $-0.024 \mathrm{~ns}$ & $0.40 * * *$ & $0.69 * * *$ & $-0.049 * *$ & $0.63 * * *$ & $0.011 \mathrm{~ns}$ & $0.58 * * *$ & $-0.18 * * *$ \\
\hline MLD $0.7 \mathrm{~d} f=2938$ & $-0.038 *$ & $0.37 * * *$ & $0.61 * * *$ & $-0.17 * * *$ & $0.57 * * *$ & $-0.02 \mathrm{~ns}$ & $0.54 * * *$ & $-0.28 * * *$ \\
\hline MLD $0.8 \mathrm{~d} f=2937$ & $-0.069 * * *$ & $0.46 * * *$ & $0.52 * * *$ & $-0.070 * * *$ & $0.52 * * *$ & $-2.5 \mathrm{e}-05 \mathrm{~ns}$ & $0.50 * * *$ & $-0.42 * * *$ \\
\hline CVHD $0.3 \mathrm{~d} f=2916$ & $-0.011 \mathrm{~ns}$ & $0.33 * * *$ & $0.54 * * *$ & $0.34 * * *$ & $0.57 * * *$ & $0.15^{* * *}$ & $0.44 * * *$ & $0.046^{*}$ \\
\hline CVHD $0.4 \mathrm{~d} f=2912$ & $0.023 \mathrm{~ns}$ & $0.30 * * *$ & $0.51 * * *$ & $0.32 * * *$ & $0.52 * * *$ & $0.15^{* * *}$ & $0.40 * *$ & $0.065 * * *$ \\
\hline CVHD $0.5 \mathrm{~d} f=2920$ & $0.038 *$ & $0.30 * * *$ & $0.51 * * *$ & $0.31 * * *$ & $0.50 * * *$ & $0.16^{* * *}$ & $0.38 * * *$ & $0.062 * * *$ \\
\hline CVHD $0.6 \mathrm{~d} f=2906$ & $0.066 * * *$ & $0.30 * * *$ & $0.49 * * *$ & $0.31 * * *$ & $0.48 * * *$ & $0.17 * * *$ & $0.35 * * *$ & $0.044 *$ \\
\hline CVHD $0.7 \mathrm{~d} f=2865$ & $0.07 * * *$ & $0.33 * * *$ & $0.46^{* * *}$ & $0.36 * * *$ & $0.47 * * *$ & $0.18 * * *$ & $0.34 * * *$ & $0.02 \mathrm{~ns}$ \\
\hline CVHD $0.8 \mathrm{~d} f=2728$ & $0.047 *$ & $0.36^{* * *}$ & $0.37 * * *$ & $0.50 * * *$ & $0.37 * * *$ & $0.21 * * *$ & $0.26 * * *$ & $0.0012 \mathrm{~ns}$ \\
\hline CVLD $0.3 \mathrm{~d} f=2937$ & $0.12 * * *$ & $0.067 * * *$ & $0.11 * * *$ & $0.20 * * *$ & $0.071 * * *$ & $0.11 * * *$ & $0.021 \mathrm{~ns}$ & $0.090 * * *$ \\
\hline CVLD $0.4 \mathrm{~d} f=2937$ & $0.083 * * *$ & $0.19 * * *$ & $0.30 * * *$ & $0.23 * * *$ & $0.28 * * *$ & $0.13 * * *$ & $0.20 * * *$ & $0.044^{*}$ \\
\hline CVLD $0.5 \mathrm{~d} f=2937$ & $0.075 * * *$ & $0.21 * * *$ & $0.35 * * *$ & $0.22 * * *$ & $0.33 * * *$ & $0.13 * * *$ & $0.24 * * *$ & $0.034 \mathrm{~ns}$ \\
\hline CVLD $0.6 \mathrm{~d} f=2938$ & $0.07 * * *$ & $0.23 * * *$ & $0.37 * * *$ & $0.22 * * *$ & $0.36 * * *$ & $0.13 * * *$ & $0.26 * * *$ & $0.022 \mathrm{~ns}$ \\
\hline CVLD $0.7 \mathrm{~d} f=2938$ & $0.060 * * *$ & $0.25 * * *$ & $0.36^{* * *}$ & $0.24 * * *$ & $0.38 * * *$ & $0.13 * * *$ & $0.27 * * *$ & $0.004 \mathrm{~ns}$ \\
\hline CVLD $0.8 \mathrm{~d} f=2937$ & $0.044 *$ & $0.26 * * *$ & $0.36 * * *$ & $0.30 * * *$ & $0.40 * * *$ & $0.14 * * *$ & $0.28 * * *$ & $0.012 \mathrm{~ns}$ \\
\hline PHD $0.3 \mathrm{~d} f=2938$ & $-0.037 *$ & $0.47 * * *$ & $0.62 * * *$ & $0.28 * * *$ & $0.64 * * *$ & $0.14 * * *$ & $0.55 * * *$ & $-0.13 * * *$ \\
\hline PHD $0.4 \mathrm{~d} f=2938$ & $-0.02 \mathrm{~ns}$ & $0.47 * * *$ & $0.58 * * *$ & $0.30 * * *$ & $0.58 * * *$ & $0.14 * * *$ & $0.51 * * *$ & $-0.17 * * *$ \\
\hline PHD $0.5 \mathrm{~d} f=2938$ & $-0.027 \mathrm{~ns}$ & $0.50 * * *$ & $0.55 * * *$ & $0.31 * * *$ & $0.57 * * *$ & $0.15^{* * *}$ & $0.50 * * *$ & $-0.20 * * *$ \\
\hline PHD $0.6 \mathrm{~d} f=2938$ & $-0.045^{*}$ & $0.53 * * *$ & $0.51 * * *$ & $0.37 * * *$ & $0.56 * * *$ & $0.16 * * *$ & $0.49 * * *$ & $-0.25 * * *$ \\
\hline PHD $0.7 \mathrm{~d} f=2938$ & $-0.082 * * *$ & $0.57 * * *$ & $0.48 * * *$ & $0.48 * * *$ & $0.54 * * *$ & $0.18 * * *$ & $0.48 * * *$ & $-0.27 * * *$ \\
\hline PHD $0.8 \mathrm{~d} f=2938$ & $-0.12 * * *$ & $0.57 * * *$ & $0.42 * * *$ & $0.61 * * *$ & $0.47 * * *$ & $0.21 * * *$ & $0.42 * * *$ & $-0.20 * * *$ \\
\hline
\end{tabular}

Pearson's product-moment correlation under $H_{o}$ true correlation is equal to 0 . The density criterion $d c$ ranges from 0.3 to $0.8 \mathrm{~kg} \mathrm{dm}{ }^{-3}$

$n s$ Not significant, $R W$ ring width, $M R D$ mean ring density, $M I D$ minimum ring density, $M A D$ maximum ring density, $E W D$ earlywood density, $L W D$ latewood density, $E W P$ earlywood proportion, SEQ $i$ MHD mean of high-density segment, $M L D$ mean of low-density segment, d $f$ degree of freedom for each variable

Associated probabilities $(* * *) p<0.001,(* *) p<0: 01,(*) p<0.05$

\section{References}

Aber J, Neilson RP, McNulty S, Lenihan JM, Bachelet D, Drapek RJ (2001) Forest processes and global environmental change: predicting the effects of individual and multiple stressors. Bioscience 51(9):735-751. doi:10.1641/0006-3568(2001)051 [0735:FPAGEC]2.0.CO;2

Adams HD, Guardiola-Claramonte M, Barron-Gafford GA, Villegas JC, Breshears DD, Zou CB, Troch PA, Huxman TE (2009) Temperature sensitivity of drought-induced tree mortality portends increased regional die-off under global-change-type drought. Proc Natl Acad Sci 106(17 (avril 28)):7063-7066. doi:10.1073/pnas.0901438106

Alberto FJ, Aitken SN, Alia R, Gonzalez-Martinez SC, Hanninen H, Kremer A, Lefevre F et al (2013) Potential for evolutionary

responses to climate change-evidence from tree populations. Glob Change Biol 19(6):1645-1661. doi:10.1111/gcb.12181

Allen CD, Macalady AK, Chenchouni H, Bachelet D, McDowell N, Vennetier M, Kitzberger T et al (2010) A global overview of drought and heat-induced tree mortality reveals emerging climate change risks for forests. For Ecol Manag 259(4 (février 5)):660-684. doi:10.1016/j.foreco.2009.09.001

Anderegg WRL, Berry JA, Smith DD, Sperry JS, Anderegg LDL, Field CB (2012) The roles of hydraulic and carbon stress in a widespread climate-induced forest die-off. Proc Natl Acad Sci 109(1 (janvier 3)):233-237. doi:10.1073/pnas.1107891109

Anderegg LDL, Anderegg WRL, Abatzoglou J, Hausladen AM, Berry JA (2013) Drought characteristics' role in widespread aspen forest mortality across Colorado, USA. Glob Change Biol 19 (5 (mai)):1526-1537. doi:10.1111/gcb.12146
660

661

662

663

664

665

666

667

668

669

670

671

672

673

674 
Aranda I, Gil-Pelegrín E, Gascó A, Guevara MA, Cano JF, De Miguel M, Ramírez-Valiente JA et al (2012) Drought response in forest trees: from the species to the gene. In: Aroca R (ed) Plant responses to drought stress. Springer, Berlin, pp 293-333. doi:10.1007/978-3-642-32653-0_12

Barigah TS, Charrier O, Douris M, Bonhomme M, Herbette S, Améglio T, Fichot R, Brignolas F, Cochard H (2013) Water stress-induced xylem hydraulic failure is a causal factor of tree mortality in beech and poplar. Ann Bot 112(7 (janvier 11)):1431-1437. doi:10.1093/aob/mct204

Breda N, Huc R, Granier A, Dreyer E (2006) Temperate forest trees and stands under severe drought: a review of ecophysiological responses, adaptation processes and long-term consequences. Ann For Sci 63(6):625-644

Cregg BM (2004) Improving drought tolerance of trees: theoretical and practical considerations. In: Fernandez T, Davidson CG (eds) Nursery crops development, Evaluation, production and use, vol 1. International Society Horticultural Science, Leuven, pp 147-158

Cruiziat P, Cochard H, Ameglio T (2002) Hydraulic architecture of trees: main concepts and results. Ann For Sci 59(7):723-752

Dalla-Salda G, Martinez-Meier A, Cochard H, Rozenberg P (2009) Variation of wood density and hydraulic properties of Douglasfir (Pseudotsuga menziesii (Mirb.) Franco) clones related to a heat and drought wave in France. For Ecol Manag 257(1):182-189

Dalla-Salda G, Martinez-Meier A, Cochard H, Rozenberg P (2011) Genetic variation of xylem hydraulic properties shows that wood density is involved in adaptation to drought in douglas-fir (Pseudotsuga Menziesii (Mirb.)). Ann For Sci 68(4). doi:10. 1007/s13595-011-0091-1

Domec JC, Gartner BL (2002) How do water transport and water storage differ in coniferous earlywood and latewood? J Exp Bot 53(379):2369-2379

Eilmann B, Rigling A (2012) Tree-growth analyses to estimate tree species' drought tolerance. Tree Physiol 32(2 (février)):178-187. doi:10.1093/treephys/tps004

Franceschini T, Longuetaud F, Bontemps J-D, Bouriaud O, Caritey B-D, Leban J-M (2013) Effect of ring width, cambial age, and climatic variables on the within-ring wood density profile of Norway spruce Picea Abies (L.) Karst. Trees:1-13. doi:10.1007/ s00468-013-0844-6

Guay R, Gagnon R, Morin H (1992) A new automatic and interactive tree ring measurement system based on a line scan camera. For Chron 68(1):138-141

Hacke UG, Sperry JS (2001) Functional and ecological xylem anatomy. Persp Plant Ecol Evol System 4(2). doi:10.1078/14338319-00017

Hacke UG, Sperry JS, Pockman WT, Davis SD, McCulloh KA (2001) Trends in wood density and structure are linked to prevention of xylem implosion by negative pressure. Oecologia 126(4). doi:10. $1007 / \mathrm{s} 004420100628$

Hanson PJ, Weltzin JF (2000) Drought disturbance from climate change: response of US forests. Sci Total Environ 262(3):205-220. doi:10.1016/S0048-9697(00)00523-4

Hiromi T, Ichie T, Kenzo T, Ninomiya I (2012) Interspecific variation in leaf water use associated with drought tolerance in four emergent Dipterocarp species of a tropical rain forest in Borneo. J For Res 17(4). doi:10.1007/s10310-011-0303-4

Ivkovic M, Rozenberg P (2004) A method for describing and modelling of within-ring wood density distribution in clones of three coniferous species. Ann For Sci 61(8):759-769

Joly D, Brossard T, Cardot H, Cavailhes J, Hilal M, Wavresky P (2010) Les types de climats en France, une construction spatiale. Cybergeo (juin 18). doi:10.4000/cybergeo.23155. http://cyber geo.revues.org/23155
Jones HG (1992) Plants and microclimate: a quantitative approach to environmental plant physiology. Cambridge University Press, Cambridge

Jump AS, Hunt JM, Martinez-Izquierdo JA, Penuelas J (2006) Natural selection and climate change: temperature-linked spatial and temporal trends in gene frequency in Fagus Sylvatica. Mol Ecol 15(11 (octobre)):3469-3480. doi:10.1111/j.1365-294X.2006. 03027.x

Kavanagh KL, Bond BJ, Aitken SN, Gartner BL, Knowe S (1999) Shoot and root vulnerability to xylem cavitation in four populations of Douglas-fir seedlings. Tree Physiol 19(1 (janvier 1)):31-37. doi:10.1093/treephys/19.1.31

Koubaa A, Isabel N, Zhang SY, Beaulieu J, Bousquet J (2005) Transition from Juvenile to mature wood in black spruce (Picea Mariana (Mill.) BSP). Wood Fiber Sci 37(3):445-455

Kraft NJB, Metz MR, Condit RS, Chave J (2010) The relationship between wood density and mortality in a global tropical forest data. Set New Phytol 188(4):1124-1136. doi:10.1111/j.14698137.2010.03444.x

Kukowski KR, Schwinning S, Schwartz BF (2013) Hydraulic responses to extreme drought conditions in three co-dominant tree species in shallow soil over bedrock. Oecologia 171(4). doi:10.1007/s00442-012-2466-X

Lamy J-B, Bouffier L, Burlett R, Plomion C, Cochard H, Delzon S (2011) Uniform selection as a primary force reducing population genetic differentiation of cavitation resistance across a species range. PLoS One 6(8):e23476. doi:10.1371/journal.pone. 0023476

Lamy J-B, Lagane F, Plomion C, Cochard H, Delzon S (2012) Microevolutionary patterns of juvenile wood density in a pine species. Plant Ecol 213(11 (novembre)):1781-1792. doi:10.1007/s11258012-0133-2

Larjavaara M, Muller-Landau HC (2010) Rethinking the value of high wood density. Funct Ecol 24(4):701-705. doi:10.1111/j. 1365-2435.2010.01698.x

Lenz O, Schar E, Schweingruber Fh (1976) Methodological problems relative to measurement of density and width of growth rings by X-ray densitogrames of wood. Holzforschung 30(4):114-123. doi:10.1515/hfsg.1976.30.4.114

Martinez-Meier A, Sanchez L, Pastorino M, Gallo L, Rozenberg P (2008a) What is hot in tree rings? The wood density of surviving Douglas-firs to the 2003 drought and heat wave. For Ecol Manage 256(4):837-843

Martinez-Meier A, Sanchez L, Salda GD, Pastorino MJM, Gautry JY, Gallo LA, Rozenberg P (2008b) Genetic control of the tree-ring response of Douglas-fir (Pseudotsuga menziesii (Mirb.) Franco) to the 2003 drought and heat-wave in France-art. no. 102. Ann For Sci 65(1):102

Martinez-Vilalta, J, Mencuccini M, Vayreda J, Retana J (2010) Interspecific variation in functional traits, not climatic differences among species ranges, determines demographic rates across 44 temperate and mediterranean tree species. J Ecol (Oxford) 98(6). doi:10.1111/j.1365-2745.2010.01718.x

Martinez-Vilalta J, Lloret F, Breshears DD (2012) Drought-induced forest decline: causes, scope and implications. Biol Lett 8(5):689-691. doi:10.1098/rsbl.2011.1059

McDowell N, Pockman WT, Allen CD, Breshears DD, Cobb N, Kolb T, Plaut J, et al. (2008) Mechanisms of plant survival and mortality during drought: why do some plants survive while others succumb to drought? New Phytol 178(4). doi:10.1111/j. 1469-8137.2008.02436.x

Pharis RP, Ferrell WK (1966) Differences in drought resistance between coastal and inland sources of Douglas fir. Canad J Bot 44(12):1651-1659. doi:10.1139/b66-177

Pluess AR, Weber P (2012) Drought-adaptation potential in Fagus Sylvatica: linking moisture availability with genetic diversity 
and dendrochronology. PLoS One 7 (3). doi:10.1371/journal. pone. 0033636

Polge H (1978) 15 years of wood radiation densitometry. Wood Sci Technol 12(3):187-196

Poorter L, McDonald I, Alarcon A, Fichtler E, Licona JC, PenaClaros M, Sterck F, Villegas Z, Sass-Klaassen U (2010) The importance of wood traits and hydraulic conductance for the performance and life history strategies of 42 rainforest tree species. New Phytol 185(2). doi:10.1111/j.1469-8137.2009. 03092.x

R Core Team (2013) R: a language and environment for statistical computing. R Foundation for Statistical Computing, Vienna. http://www.R-project.org

Rathgeber CBK, Decoux V, Leban JM (2006) Linking intra-tree-ring wood density variations and tracheid anatomical characteristics in Douglas fir (Pseudotsuga menziesii (Mirb.) Franco). Ann For Sci 63(7):699-706

Rosner S, Klein A, Muller U, Karlsson B (2007) Hydraulic and mechanical properties of young Norway spruce clones related to growth and wood structure. Tree Physiol 27(8):1165-1178

Rozenberg P, Franc A, Mamdy C, Launay J, Schermann N, Bastien JC (1999) Genetic control of stiffness of standing Douglas fir; from the standing stem to the standardised wood sample, relationships between modulus of elasticity and wood density parameters Part II. Ann For Sci 56(2):145-154
Sergent A-S (2011) Diversité de la réponse au déficit hydrique et vulnérabilité au dépérissement du douglas. Université d'Orléans, INRA Orléans France

Sergent A-S, Rozenberg P, Bréda N (2012) Douglas-Fir is vulnerable to exceptional and recurrent drought episodes and recovers less well on less fertile sites. Ann For Sci 1-12. doi:10.1007/s13595012-0220-5

Van Mantgem PJ, Stephenson NL, Byrne JC, Daniels LD, Franklin JF, Fule PZ, Harmon ME et al (2009) Widespread increase of tree mortality rates in the Western US. Science 323(5913 (janvier 23)):521-524. doi:10.1126/science. 1165000

Wang W, Changhui P, Kneeshaw DD, Larocque GR, Luo Z (2012) Drought-induced tree mortality: ecological consequences, causes, and modeling. Environ Rev 20(2 (juin)):109-121. doi:10.1139/a2012-004

Williams AP, Allen CD, Miliar CI, Swetnam TW, Michaelsen J, Still CJ, Leavitt SW (2010) Forest responses to increasing aridity and warmth in the Southwestern US. Proc Natl Acad Sci USA 107 (50). doi:10.1073/pnas.0914211107

Wortemann R, Herbette S, Barigah TS, Fumanal B, Alia R, Ducousso A, Gomory D, Roeckel-Drevet P, Cochard H (2011) Genotypic variability and phenotypic plasticity of cavitation resistance in Fagus sylvatica L. across Europe. Tree Physiol 31(11 (novembre 1)):1175-1182. doi:10.1093/treephys/tpr101 